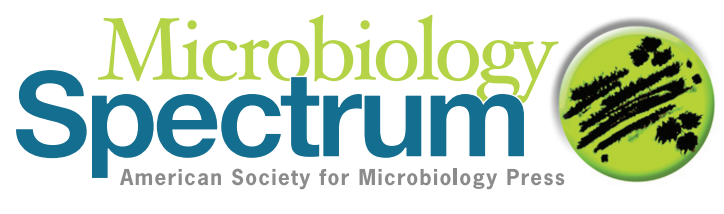

\title{
Environmental and Adaptive Changes Necessitate a Paradigm Shift for Indicators of Fecal Contamination
}

\begin{abstract}
PEDRO TEIXEIRA, ${ }^{1,2,3^{*}}$ DANIEL SALVADOR, ${ }^{2,4^{*}}$ JOÃO BRANDÃO, ${ }^{2,3}$ WARISH AHMED, ${ }^{5}$ MICHAEL J. SADOWSKY, ${ }^{6}$ and ELISABETE VALÉRIO ${ }^{3}$

${ }^{1}$ Câmara Municipal de Lisboa, Direcção Municipal do Ambiente, Estrutura Verde, Clima e Energia, Laboratório de Bromatologia e Águas, Lisbon, Portugal; ${ }^{2}$ Centro de Estudos do Ambiente e do Mar (CESAM), Faculdade de Ciências da Universidade de Lisboa, Lisbon, Portugal; ${ }^{3}$ Departamento de Saúde Ambiental, Instituto Nacional de Saúde Doutor Ricardo Jorge, Lisbon, Portugal; ${ }^{4}$ Instituto de Saúde Ambiental (ISAMB), Faculdade de Medicina da Universidade de Lisboa, Lisbon, Portugal; ${ }^{5} \mathrm{CSIRO}$ Land and Water, Ecosciences Precinct, Dutton Park, Australia; ${ }^{6}$ BioTechnology Institute and Departments of Soil, Water, \& Climate and Plant and Microbial Biology, University of Minnesota, St. Paul, Minnesota, USA
\end{abstract}

ABSTRACT Changes in the occurrence, distribution, and seasonal variation of waterborne pathogens due to global climate change may increase the risk of human exposure to these microorganisms, thus heightening the need for more reliable surveillance systems. Routine monitoring of drinking water supplies and recreational waters is performed using fecal indicator microorganisms, such as Escherichia coli, Enterococcus spp., and coliphages. However, the presence and numbers of these indicators, especially $E$. coli and Enterococcus spp., do not correlate well with those of other pathogens, especially enteric viruses, which are a major cause of waterborne outbreaks associated with contaminated water and food, and recreational use of lakes, ponds, rivers, and estuarine waters. For that reason, there is a growing need for a surveillance system that can detect and quantify viral pathogens directly in water sources to reduce transmission of pathogens associated with fecal transmission. In this review, we present an updated overview of relevant waterborne enteric viruses that we believe should be more commonly screened to better evaluate water quality and to determine the safety of water use and reuse and of epidemiological data on viral outbreaks. We also discuss current methodologies that are available to detect and quantify these viruses in water resources. Finally, we highlight challenges associated with virus monitoring. The information presented in this review is intended to aid in the assessment of human health risks due to contact with water sources, especially since current environmental and adaptive changes may be creating the need for a paradigm shift for indicators of fecal contamination.

\section{INTRODUCTION: WHY THIS REVIEW?}

Current environmental changes, and subsequent adaptive alterations in microorganisms, are expected to adversely impact paradigms used in water quality safety criteria. Extreme weather events are foreseen to increase in intensity and frequency ( 1 ) due, in large part, to global warming, which may cause destruction of infrastructure needed to separate sewage and drainage from clean drinking and recreational waters and damage due to elevated water levels and high tides. For example, in 2010 during an unusual tropical storm in Madeira, Portugal, $108 \mathrm{~mm}$ of rainfall was recorded between

\footnotetext{
Received: 12 June 2019, Accepted: 12 December 2019 Published: 27 March 2020

Editor: Michael Sadowsky, BioTechnology Institute, University of Minnesota, St. Paul, MN

Citation: Teixeira P, Salvador D, Brandão J, Ahmed W, Sadowsky MJ, Valério E. 2020. Environmental and adaptive changes necessitate a paradigm shift for indicators of fecal contamination, Microbiol Spectrum 8(2):ERV-0001-2019. doi:10.1128/microbiolspec.ERV0001-2019.

Correspondence: Elisabete Valério, elisabete.valerio@insa.minsaude.pt

*Pedro Teixeira and Daniel Salvador contributed equally to this work. (c) 2020 American Society for Microbiology. All rights reserved.
} 
6 and 11 a.m. at the Funchal weather station, and $165 \mathrm{~mm}$ at Pico do Arieiro (1,818 m altitude) (2). The south of the island was severely affected by flash floods and mudslides. The degree of devastation was substantial and costly, in terms of both lives lost and economics. As a result of the storm, numbers of the fecal indicator bacteria (FIB) Enterococcus spp. and Escherichia coli, and sporulating fungi, increased dramatically in both sand and water until September of the same year. Bathing water and sand quality monitoring months later revealed that FIB abundances in both water and sand were profoundly altered for 3 months following the event ( $\underline{3})$.

Besides extreme weather events, natural aging of drinking water distribution pipes may also cause significant water quality issues. In 2016 and in 2018, Finland reported two outbreaks of gastrointestinal illness affecting about 450 people each year, which in 2016 was caused by sapovirus, human adenovirus (HAdV), and Dientamoeba fragilis, and in 2018, by human astrovirus, norovirus (NoV), and enterotoxigenic E. coli (4). The outbreaks were determined to be a result of cross-contamination between untreated wastewater and drinking water due to aging of distribution pipes (4). Reports of contamination by wastewater like the ones described above are occurring more frequently due to extreme weather, aging of infrastructure, and operational errors (4-6). Therefore, it is important to be proactive and to adopt regulations to meet the needs of a changing world.

In 2015, a review of the United States of America's Recreational Water Quality Criteria (RWQC) pointed out alternative water safety parameters for recreational waters $(\underline{7}, \underline{8})$. The rationale behind this review came from a discussion by experts on the use of traditional and alternative FIB. One of the main points of the discussion was that more appropriate fecal indicators are needed, such as Bacteroidales, since they are more exclusively related to fecal pollution than traditional FIB. This is particularly true for Enterococcus spp. and $E$. coli that may proliferate in the environment, especially in sands and sediments and on aquatic vegetation (9-11). Despite these limitations, FIB monitoring has been useful for assessing contamination due to significant fecal loading events such as large sewage spills. Use of alternative FIB such as Bacteroides or phages would likely provide improved health protection against contaminated waters. Fujioka et al. (ㄱ) described the use of human enteric viruses as an alternative to the currently used FIB, as they are the cause of most gastrointestinal illness associated with contaminated water $(\underline{7}, \underline{12})$. One limitation of enteric virus monitoring is that it requires a large volume of sample, on the scale of 10 to 100 liters, for their detection because viruses tend to be at low concentrations in recreational waters. Human polyomavirus $(\mathrm{HPyV})$ was suggested as a proxy for enteric viruses (13). This virus is excreted in human urine in greater numbers, making it more easily detectable in untreated sewage (i.e., mixture of feces, urine, and water) than other enteric viruses, such as NoV or enterovirus (EV), which are excreted by infected individuals only (14). Other sewage-associated viruses currently in use for surveillance are HAdV (15), pepper mild mottle virus (16), and crAssphage (17). Although viral markers such as HAdV and HPyV are highly host specific $(13,18,19)$, their concentration in sewage may vary by 1 to 2 orders of magnitude $(13,20)$. It is worth mentioning that $\mathrm{HPyV}$, pepper mild mottle virus, and crAssphage are indicators and not pathogens. Virus monitoring is not commonly used for routine waterquality monitoring throughout the world, although certain laboratories in the United States and Australia have been screening for enteric viruses. This approach needs to be expanded to other laboratories.

In the following sections, we focus on the main enteric viruses which are objects of frequent discussions at regulatory and scientific meetings. We recommend their expanded use in water quality assessment and monitoring, along with the methodologies currently available to detect and quantify viruses, and we review the challenges associated with virus monitoring. This review intends to serve as a learning resource about water regulations, since environmental and adaptive changes will require a paradigm shift of the current combination of indicators of fecal contamination and other pathogens and opportunists.

\section{BACTERIAL INDICATORS AS SURROGATES FOR ENTERIC VIRUSES}

From a microbiological standpoint, waterborne pathogens, namely bacteria, viruses, protozoa, and parasitic helminths, are one of the main causes of gastrointestinal illnesses (21). The concentrations of each pathogen are not equal and may vary in the host and receiving environments due to dilution, decay, and factors such as environmental stress. In addition, a wide variety of pathogens can be present in the feces of humans and animals (22). Therefore, direct monitoring of all pathogens is not a technologically feasible option and can be costly. Thus, routine microbiological testing of drinking water supplies and recreational waters is performed 
using FIB or viral surrogates, such as somatic coliphages and F-specific phages (23). The most commonly used FIB are E. coli and Enterococcus spp. However, these FIB do not correlate well with human enteric virus numbers, especially viruses and protozoa in the environment, and can be found in the absence of pathogens, or vice versa (24). One of the major reasons why virus and FIB levels may not correlate is because FIB can replicate in the environment without a host; however, viruses need to be inside the host (or cells) to replicate. Moreover, viruses are more tolerant to disinfection or UV radiation than FIB, due in part to their size, surface charge, and other properties (25). In addition, due to the low infectious doses of viruses, they pose definite health risks to humans (26).

Chlorine is the most commonly used agent for water disinfection, since it rapidly inactivates most pathogens that cause disease in humans (27). However, enteric viruses have a moderate to high tolerance to chlorine compared to FIB $(28,29)$. Therefore, FIB are not a reliable indicator of the presence/absence of enteric viruses in the drinking water supply network or in recreational waters. For those reasons, there is a growing need for a surveillance system that can detect and quantify some of the most relevant viral pathogens directly in water sources and thus aid in the protection of human health.

\section{WATERBORNE GASTROINTESTINAL ILLNESS (FECAL ORIGIN)}

Population growth and urbanization put tremendous pressure on the quantity and quality of the planet's water resources $(30,31)$. About $90 \%$ of human deaths occur due to diarrheal illnesses that have been attributed to contaminated water and an inadequate or complete lack of sanitation $(\underline{32}, \underline{33})$. Most enteric viruses present in wastewater treatment plants (WWTPs) originate from human feces (34). Over 200 enteric viruses known to infect humans are considered pathogens because of their high resistance to treatment processes and their low infectious doses (35). To appropriately eliminate these viruses, it is necessary to use tertiary treatment processes involving chlorine, ozone, and exposure to UV light in drinking water treatment plants and WWTPs (36-38). However, due mainly to cost issues, many of the rather complex treatments are not always available in most DWTPs or drinking water treatment plants worldwide. The viruses' ability to survive the water treatment processes and their subsequent discharge into fresh, marine, and estuarine water bodies pose serious health risks to humans (39).

\section{ENTERIC VIRUSES OF PUBLIC HEALTH SIGNIFICANCE}

The World Health Organization (WHO) has classified viruses as having a moderate to high significance on human health (40). The viruses HAdV and astrovirus are classified as having moderate health significance, whereas EV, hepatitis A (HAV) and E (HEV) viruses, NoV, rotavirus $(\mathrm{RoV})$, sapovirus $(\mathrm{SaV})$, and parechoviruses (PEVs) are classified as having high significance (40).

Enteric viruses require human hosts to propagate and are transmitted to humans via the fecal-oral route. They are frequently detected in contaminated food and water (41), and their transmission routes are quite diverse, ranging from consumption of contaminated food or water to contact with feces, vomitus, or aerosols to person-to-person spread (Fig. 1).

Enteric viruses are excreted in high numbers, up to $10^{10} / \mathrm{g}$ of feces, by infected individuals, and their infectious doses may vary by many orders of magnitude (Table 1).

\section{Human Adenovirus}

HAdVs are members of the Adenoviridae family, classified in the genus Mastadenovirus, and have a DNA genome. HAdV classification comprises seven species (A to $G$ ) and over 80 genotypes, which can infect a wide range of tissues (42-44). HAdV can cause respiratory infections, gastroenteritis, conjunctivitis, and cystitis, as well as infections in other organs, e.g., the central nervous system and sexual organs (45-51). Their infective dose is low, and as little as 5 infectious units can cause disease in susceptible individuals (Table 1).

Transmission of HAdV occurs mainly through the fecal-oral route and aerosol inhalation (52, 53). Since they are persistent in the feces, urine, and respiratory secretions of infected individuals (48), they are highly prevalent in untreated wastewater $(54,55)$. Current wastewater treatment options have proven to be insufficient regarding HAdV removal, even with inactivation by UV treatment or at typical effluent-free chlorine concentrations (56-59). Therefore, their persistence in wastewater may be one of the key factors of HAdV transmission, which consequently leads to public health risks with a wide range of associated outbreaks (Table 2) (60-62). However, HAdV may not be the most suitable indicator microbe for NoVs and hepatitis viruses (6365). This is mainly due to their high stability, ubiquitous distribution in many aquatic environments (including surface and groundwater, recreational water, drinking water, and wastewater [raw and treated]), considerable 
Teixeira et al.

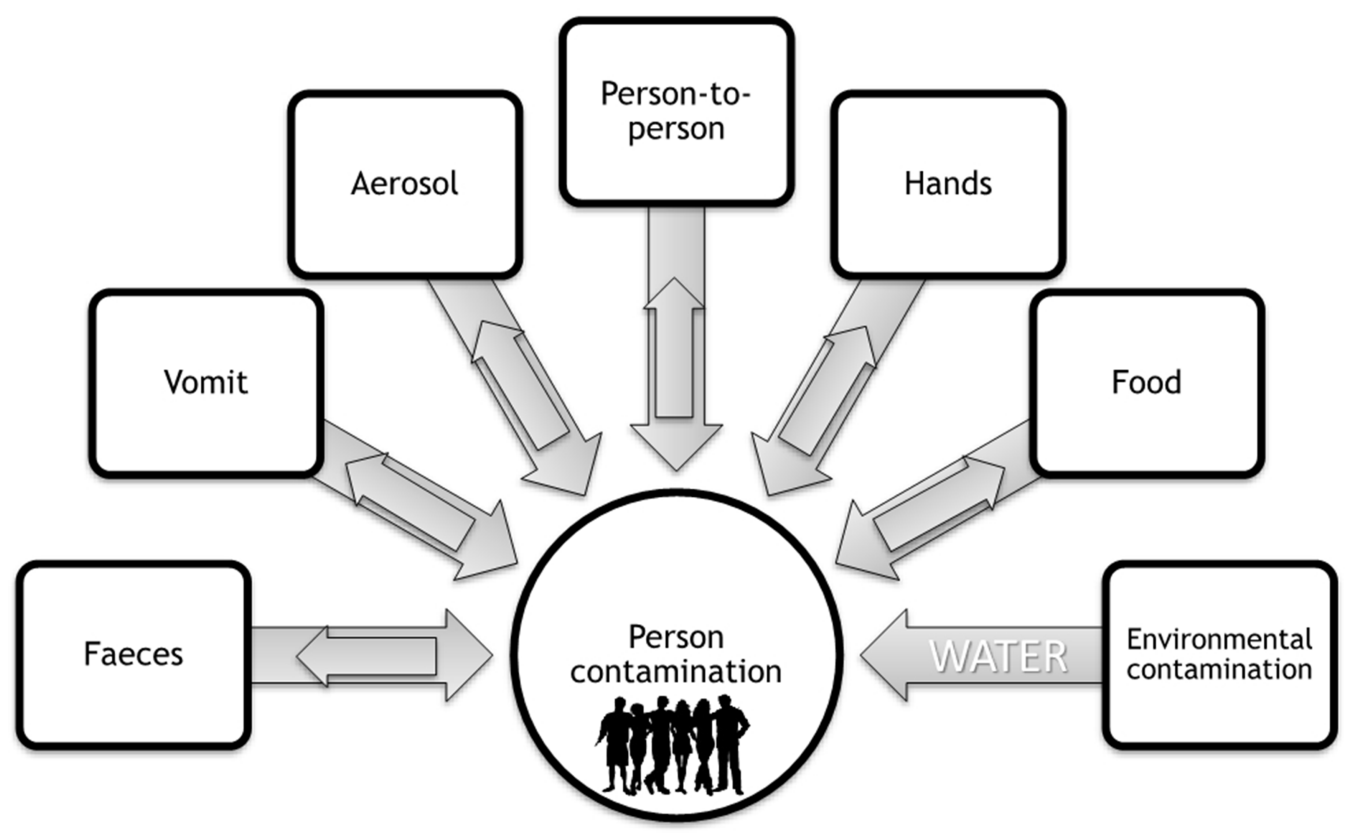

FIGURE 1 Transmission routes of enteric viruses.

TABLE 1 Symptoms, transmission pathways, and infectious doses of the most common waterborne enteric viruses in water sources

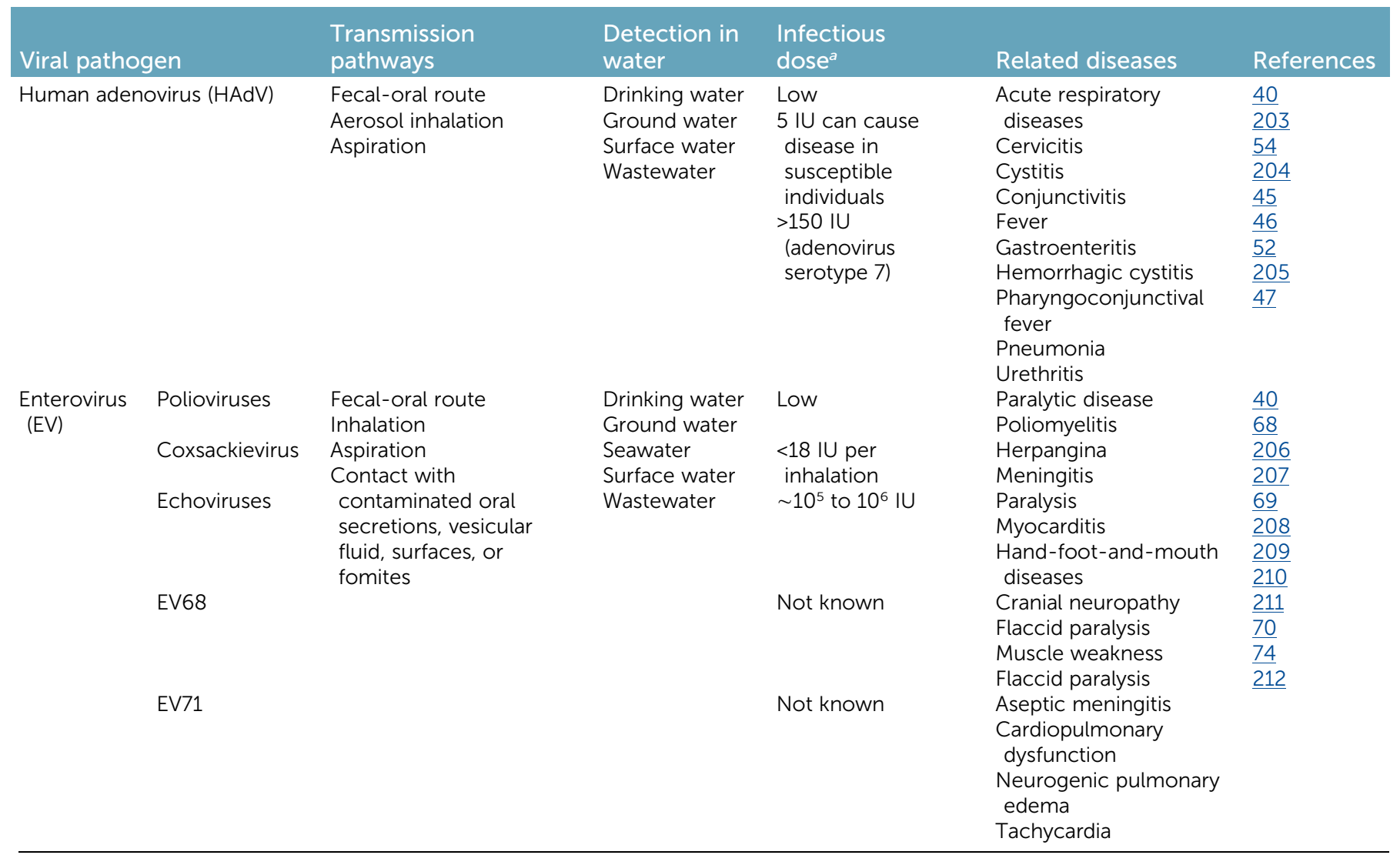


TABLE 1 Symptoms, transmission pathways, and infectious doses of the most common waterborne enteric viruses in water sources (continued)

\begin{tabular}{|c|c|c|c|c|c|}
\hline Viral pathogen & $\begin{array}{l}\text { Transmission } \\
\text { pathways }\end{array}$ & $\begin{array}{l}\text { Detection in } \\
\text { water }\end{array}$ & $\begin{array}{l}\text { Infectious } \\
\text { dose }^{a}\end{array}$ & Related diseases & References \\
\hline Norovirus (NoV) & $\begin{array}{l}\text { Fecal-oral route } \\
\text { Direct contact with an } \\
\text { infected individual }\end{array}$ & $\begin{array}{l}\text { Drinking water } \\
\text { Surface water } \\
\text { Wastewater }\end{array}$ & $\begin{array}{l}\text { Low } \\
\geq 18 \text { IU ( } 50 \% \text { human } \\
\text { infectious dose, } \\
18 \text { to } 1,015 \text { to } \\
1,320 \text { to } 2,800 \\
\text { genomic } \\
\text { equivalents) }\end{array}$ & $\begin{array}{l}\text { Abdominal cramps } \\
\text { Chills } \\
\text { Diarrhea } \\
\text { Vomiting } \\
\text { Nausea } \\
\text { Headache } \\
\text { Fever } \\
\text { Muscle aches }\end{array}$ & $\begin{array}{l}\frac{36}{40} \\
\frac{95}{213} \\
\frac{82}{76} \\
\frac{214}{215} \\
\frac{116}{216} \\
\frac{83}{94}\end{array}$ \\
\hline Hepatitis A virus (HAV) & Fecal-oral route & $\begin{array}{l}\text { Drinking water } \\
\text { Ground water } \\
\text { Seawater } \\
\text { Surface water } \\
\text { Wastewater }\end{array}$ & Low & $\begin{array}{l}\text { Abdominal discomfort } \\
\text { Anorexia } \\
\text { Dark urine } \\
\text { Diarrhea } \\
\text { Fatigue } \\
\text { Fever } \\
\text { Hepatic cell damage } \\
\text { Jaundice } \\
\text { Malaise } \\
\text { Nausea } \\
\text { Vomiting } \\
\text { Urticaria } \\
\text { Pancreatitis } \\
\text { Vasculitis } \\
\text { glomerulonephritis }\end{array}$ & $\begin{array}{l}\frac{40}{208} \\
\frac{217}{218} \\
\frac{218}{219} \\
\frac{220}{221} \\
\frac{222}{159} \\
\frac{223}{224} \\
\frac{160}{2}\end{array}$ \\
\hline Hepatitis E virus (HEV) & $\begin{array}{l}\text { Fecal-oral route } \\
\text { Transfusions with } \\
\text { contaminated blood } \\
\text { Vertical transmission } \\
\text { (maternal-fetal) }\end{array}$ & $\begin{array}{l}\text { Seawater } \\
\text { Surface water } \\
\text { Wastewater }\end{array}$ & Not known & $\begin{array}{l}\text { Jaundice } \\
\text { Vomiting } \\
\text { Loss of appetite } \\
\text { Fatigue } \\
\text { Fever } \\
\text { Darkened urine } \\
\text { Hepatalgia } \\
\text { Hepatomegaly } \\
\text { Neurological } \\
\text { complications }\end{array}$ & $\begin{array}{l}\frac{40}{\frac{409}{168}} \\
\frac{225}{178} \\
\frac{178}{226} \\
\frac{227}{228} \\
\underline{228}\end{array}$ \\
\hline
\end{tabular}

$a \mathrm{IU}$, infectious units.

${ }^{b}$ Rotavirus was excluded from the next sections because there is already a widely available vaccine for this agent.

thermal stability, and ability to survive for several months in the environment (Table 2). Thus, their survival rarely mimics that of pathogens that are present due to recent contamination ( $\underline{66})$.

\section{Enterovirus}

EVs are small, single-stranded RNA viruses of the Picornaviridae family. They have a nonenveloped icosahedral capsid with a diameter of 20 to $30 \mathrm{~nm}(\underline{40}, \underline{67})$. The EVs are divided into the polioviruses ( 3 serotypes), coxsackievirus A (23 serotypes), coxsackievirus B (6 serotypes), and echoviruses (28 serotypes) $(\underline{40}, 68)$. The most recently discovered EVs are not included in this classification and are designated by the serotype number, beginning with EV68 (40, 69, 70). The infectious doses of poliovirus and some other EVs are not known but are estimated to be low (Table 1). A previous study showed that infective rates vary with season, geography, and the age and socioeconomic status of the population sampled (1). 
Teixeira et al.

TABLE 2 Virus concentrations in wastewater, treated wastewater, surface water, groundwater, and seawater samples

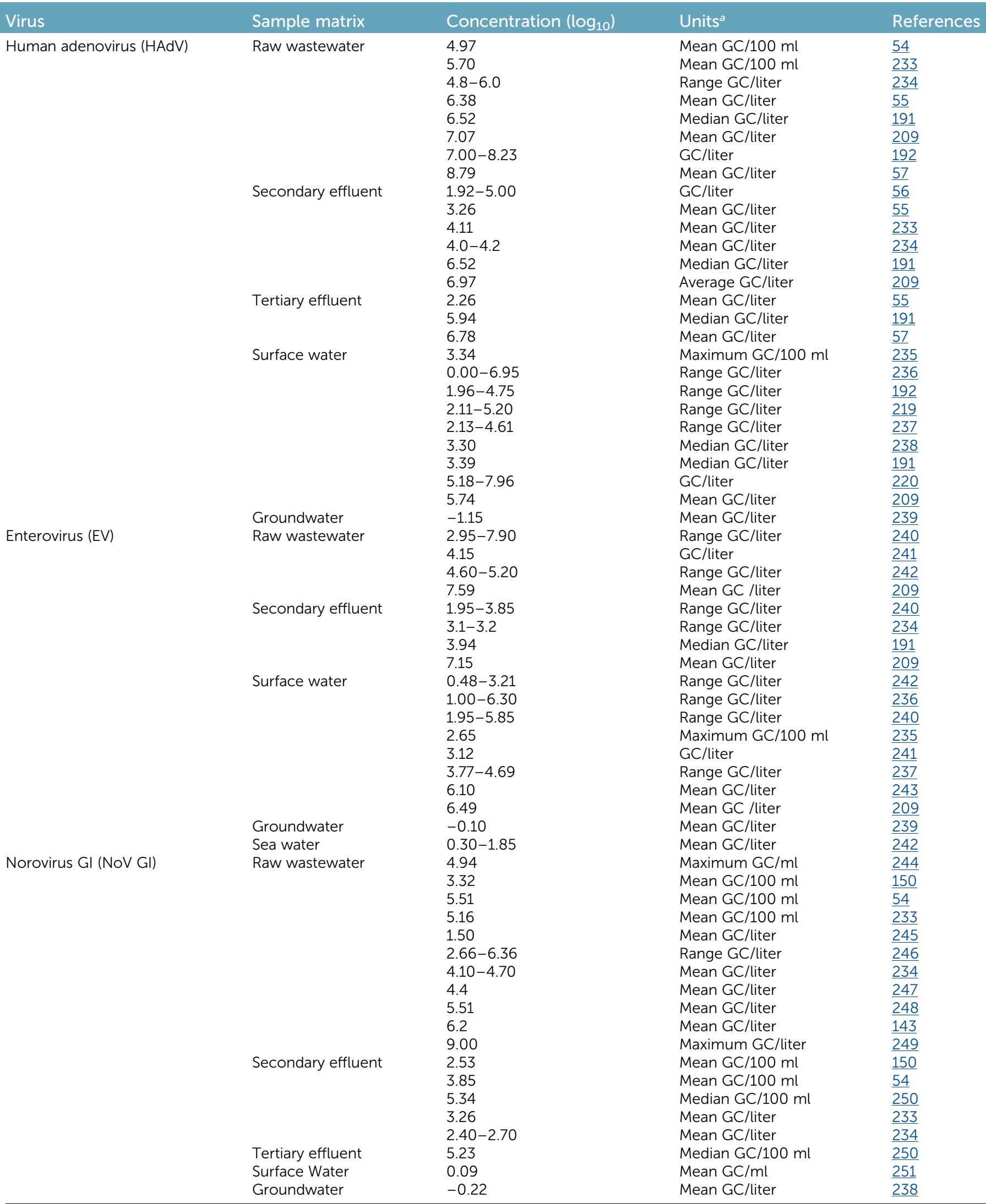


TABLE 2 Virus concentrations in wastewater, treated wastewater, surface water, groundwater, and seawater samples (continued)

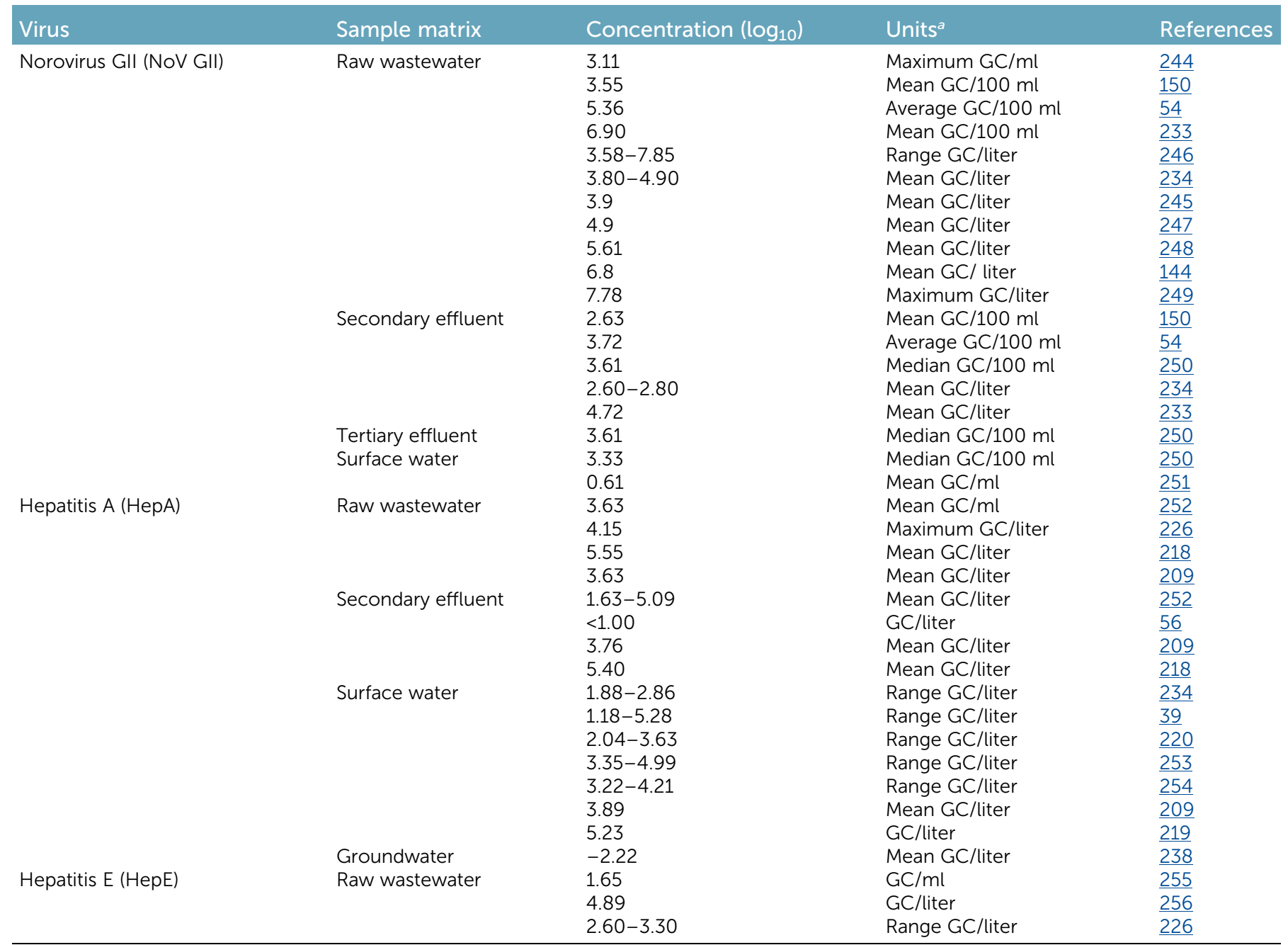

${ }^{a} \mathrm{GC}, \log _{10}$ gene copy number.

Although the predominant form of transmission is via the fecal-oral route, EV can also be transmitted by contact with contaminated oral secretions, vesicular fluid, surfaces or fomites, and respiratory droplets $(\underline{70}, \underline{71})$. These viruses cause over 30 million infections and several thousand hospitalizations per year in the United States $(40,69)$. In Portugal, a study carried out by Instituto Nacional de Saúde Doutor Ricardo Jorge using 625 fecal samples of suspected cases of EV infection (from 2010 to 2013 ) verified that $22.9 \%$ were positive for EV (그).

EV infections occur mainly in children younger than 10 years old (71), and infections may be asymptomatic or present a mild to severe symptomatology. When illness occurs, it usually takes the form of a febrile illness lasting only a few days, often accompanied by symptoms of upper respiratory tract infection or gastrointestinal illness. Although less frequent, the symptoms can become more serious according to the type of $\operatorname{EV}(\underline{62}, \underline{68}, \underline{73})$. Polioviruses can cause paralytic disease and poliomyelitis. Coxsackieviruses and echoviruses can cause herpangina, meningitis, paralysis, myocarditis, or handfoot-and-mouth diseases $(\underline{62}, \underline{68}, \underline{69})$. The most recently discovered EVs have also been associated with disease in humans. EV68 has been associated with respiratory diseases and neurological complications, namely, muscle weakness, polio-like acute flaccid paralysis, and cranial neuropathy (69). Moreover, EV71 has been associated with aseptic meningitis, cardiopulmonary dysfunction, neurogenic pulmonary edema, and tachycardia (0ㅡ). EVs are fairly contagious, and while they can be transmitted by inhalation, aspiration, contact with contaminated oral 
secretions, vesicular fluid, and surfaces or fomites, most cases are acquired by the fecal-oral route through the drinking of contaminated water (Table 1) (40). Over the years, EVs have been found in surface water, drinking water, treated and untreated wastewater, and seawater in several countries (Table 2). Symonds et al. (74) detected culturable EV in Bolivian wastewater samples from different stages of the treatment process at WWTPs. These viruses maintain the capacity to infect human cells, unlike nonculturable viruses that are not infectious. The concentration of total culturable EVs in untreated wastewater ranged from 42 to 62 infectious units $/ \mathrm{ml}$, while the concentration of total culturable EVs in treated wastewater ranged from 0.037 to 20 infectious units $/ \mathrm{ml}$.

\section{Norovirus}

NoVs are members of the Caliciviridae family, classified in the genus Norovirus (75). The NoVs are nonenveloped icosahedral viruses (28 to $30 \mathrm{~nm}$ diameter) with a single-stranded RNA genome (7.5 to $7.7 \mathrm{~kb}$ long) encoding three open reading frames (ORFs) (76). ORF 1 codes for seven nonstructural proteins involved in replication of the genome, while ORFs 2 and 3 code for the major and minor capsid proteins, respectively, whose functions remain undetermined. NoVs can be classified into six genogroups (GI to GVI), of which only GI, GII, and GIV are known to infect humans, and the GII group causes $>95 \%$ of NoV infections $(\underline{76}-79)$. Infection with NoV represents a serious and global economic problem, with an estimated economic burden of $\$ 4.2$ billion in direct health care costs and $\$ 60.3$ billion in societal costs per year $(\underline{80})$.

NoVs are a major cause of acute nonbacterial gastroenteritis among adults (11), most cases being mild with symptoms characterized by diarrhea and vomiting, followed by nausea, abdominal cramps, headache, fever, chills, and muscle aches, all of which usually last 2 to 4 days $(\underline{76}, \underline{82}, \underline{83})$. Morbidity and mortality rates of $\mathrm{NoV}$ infection are significant in young children, the elderly, and immunosuppressed and immunocompromised patients $(\underline{84}-\underline{88})$.

Globally, NoV is estimated to be responsible for almost $20 \%$ of all cases of acute gastroenteritis ( 199$)$, accounting for 677 million cases each year and over 213,000 deaths (90). NoV incidence is different in the Northern and Southern Hemispheres, presenting a peak of occurrence in the winter months, corresponding to December to February in the Northern Hemisphere and June to August in the Southern Hemisphere (91). Although mortality risks are expected to be much higher in developing countries, NoV is a problem in both low- and high-income countries, with an estimated 71,000 child deaths every year, as the high incidence of disease appears to be universal $(92,93)$.

NoVs have an estimated $50 \%$ human infectious dose of 18 to 1,015 genomic equivalents $(94)$ to 1,320 to 2,800 genomic equivalents (95) (Table 1 ), although this difference may result from different statistical methods used rather than from biological differences (96). A recent analysis indicates that host genetic susceptibility to NoV may result from the virus strain specificity (97).

Pang et al. (98) used a multiplex PCR assay and identified NoVs as the most common agents in sporadic gastroenteritis (98). Immunity after NoV infection is incomplete, and recurrent infections from the same agent are common (99), suggesting that long-term immunity may be absent $(100,101)$. Several volunteer studies also showed that immunity to NoV appears to be short lived and that resistance to one particular strain does not provide protection from other heterogeneous strains (102-104). Currently, there are no vaccines available for $\mathrm{NoV}$, although a bivalent $\mathrm{NoV}$ vaccine is in clinical trials, and other vaccines are in several stages of development (105-107).

NoV exposure, and possible outbreaks, may occur in numerous places, such as hospitals, schools, nursing homes, swimming pools, cruise ships, and restaurants $(100,108-111)$. Transmission of NoV primarily takes place via the fecal-oral contamination route, via direct contact with an infected individual and (contaminated) water and food consumption $(94,112-115)$. Exposure to the virus may occur in drinking water (116) and irrigation water (117), with NoV genogroup GI strains being more frequently associated with waterborne outbreaks $(118-120)$.

The consumption of several food products has also been associated with foodborne disease outbreaks, chiefly, bivalve shellfish (121-126). Most of these episodes are associated with sewage pollution due to system failure or incapacity, stormwater runoff, wet and dry weather overflows $(127,128)$, and boating activity (121). Moreover, fruit and vegetables may also be a source of foodborne outbreaks $(129,130)$, linked to contamination in irrigation, packaging, processing, or cooking $(112,114$, 131-133).

The vast number of contaminated water sourcessurface water, groundwater, and wastewater (raw and treated)-linked to $\mathrm{NoV}$ indicates a ubiquitous distribution of the virus, with a natural dispersion in water systems that needs to be thoroughly explored (134). In addition, the coexistence of different NoV genotypes of each genogroup can expose individuals to multiple $\mathrm{NoV}$ 
strains. Moreover, the risk of recombination within multiply infected individuals may lead to the emergence of new and possibly more virulent and pathogenic strains, with greater capacity to infect susceptible individuals or superior survival ability in the environment $(135,136)$.

NoV is highly resistant to environmental degradation in water (137-139). Thus, its presence in surface and groundwater intended for human consumption raises a potential health risk. The incidence of $\mathrm{NoV}$ in surface waters is directly linked to possible contaminated sources, with environmental conditions affecting the survival of $\mathrm{NoV}(140,141)$. Although the molecular detection of $\mathrm{NoV}$ does not suggest infectivity, the virus remains detectable in mineral and tap water for over 2 months (138) and for 728 days in groundwater (142). In a more recent study, NoV was shown to remain detectable for over 3 years and infectious for at least 61 days in groundwater (139). Seasonal variation of NoV in source water and wastewater has been documented, with higher occurrence in colder periods (143-145), with the prevalence of NoV GII being greater than GI during colder periods $(143, \underline{146})$. This reflects the GII infection incidence during this season (147).

NoV can be present in extremely high concentrations in feces, up to $10^{11} \log _{10}$ gene copy numbers $(\mathrm{GC}) / \mathrm{g}$ (148). The reported median viral load of NoV GII is $>100$-fold higher than that of GI (149). Due to their association with feces, NoVs may therefore be found in high concentrations in wastewater (Table 2). A reduction of NoV concentrations is observable in wastewater treated with mechanical systems and chlorine disinfection, but still, significant concentrations have been reported for GI and GII genogroups, e.g., 5.3 and $5.9 \log _{10}$ GC/liter, respectively (143), and $2.53 \log _{10}$ and $2.63 \log _{10} \mathrm{GC} / 100 \mathrm{ml}$, respectively (150) (Table 2).

\section{Hepatitis Viruses}

Hepatitis viruses can cause inflammation of the liver (151). Six different viruses have been identified that can provoke this infection, referred to as hepatitis A, B, C, D, $\mathrm{E}$, and $\mathrm{G}$ viruses (152). HAV and HEV are the two agents responsible for enteric infection, the main source of contamination being feces from infected individuals. Infection mainly occurs via the fecal-oral route. In contrast, hepatitis B, C, and D viruses are transmitted by the blood and are the agents responsible for parenteral infection, caused mainly by breaches in the skin or mucosa. All viral hepatitis infections have acute characteristics, but hepatitis $\mathrm{B}, \mathrm{C}$, and D can also result in chronic disease $(\underline{151}, \underline{152})$.
It has been estimated that about 4 million cases of HAV and HEV occur each year globally, with about 40,000 deaths and 40,000 cases of chronic liver damage. Infection is frequently due to the consumption of raw or undercooked bivalves/shellfish harvested from contaminated coastal waters. As these mollusks are filter feeders, they can effectively concentrate the enteric viruses from harvesting waters contaminated with sewage (153).

\section{Hepatitis A}

HAV is a small nonenveloped single-stranded RNA virus in the genus Hepatovirus (family Picornaviridae) $(62,154,155)$. These viruses have an icosahedral capsid with a diameter of 27 to $28 \mathrm{~nm}(154)$ and are often responsible for causing infectious hepatitis. Infections can be easily spread through person-to-person contact, especially in families, day care centers, schools, and other institutions. In addition, parenteral HAV transmission may occur through the use of blood products or needles during transfusions, although this is rare (151). There was a fairly widespread person-to-person outbreak reported in 2017 that occurred in several countries in Europe and the United States $(156,157)$. This outbreak was addressed by vaccination of susceptible atrisk individuals, and so far, to the best of our knowledge, there have been no waterborne follow-up events.

In approximately $90 \%$ of the cases of infection by this virus, especially in children, there is no lesion formation in the liver cells, and when lesions occur, they are reduced and no clinical symptoms are observed. In general, the severity of the disease increases with age $(\underline{40}, 158)$. When the virus enters the body via ingestion, it multiplies in the intestine and then diffuses into the liver through the bloodstream, where it can cause damage to liver cells (40, 62). HAV has a long incubation period, about 4 weeks, with a range of 2 to 6 weeks (62). This virus is not detected by routine cell culture procedures, and therefore, its epidemiology, incidence, and behavior in the environment are not well understood. Thus, the infectious dose in humans is not known $(159,160)$. However, it is thought to be as low as a single viral particle (Table 1). Hepatic cell damage results from the release of liver-specific enzymes (e.g., aspartate aminotransferase). These lesions may also result in the liver's inability to remove bilirubin from the bloodstream, which accumulates and causes jaundice and dark urine. After the incubation period (about 28 to 30 days), symptoms begin, such as fever, malaise, nausea, vomiting, anorexia, abdominal discomfort, fatigue, fever, and possibly jaundice, diarrhea, and urticaria $(\underline{40}, \underline{161})$. In severe cases, HAV 
Teixeira et al.

TABLE 3 Advantages and disadvantages of currently used virus detection methods

\begin{tabular}{|c|c|c|}
\hline Method & Advantages & Disadvantages \\
\hline Cell culture & $\begin{array}{l}\text { Provides information on the infectivity of viruses } \\
\text { Large volume of samples can be processed }\end{array}$ & $\begin{array}{l}\text { Cell lines not available for all viruses } \\
\text { Not suitable for slow-growing viruses } \\
\text { Analysis time is lengthy } \\
\text { Need to use multiple cell lines } \\
\text { Expensive }\end{array}$ \\
\hline PCR & $\begin{array}{l}\text { Detection/nondetection } \\
\text { Sensitive } \\
\text { Specific } \\
\text { Can be multiplexed } \\
\text { Results can be obtained in } 4-6 \mathrm{~h}\end{array}$ & $\begin{array}{l}\text { Does not differentiate between infectious and } \\
\text { noninfectious viruses } \\
\text { Nonquantitative } \\
\text { Can be affected by inhibition of the PCR }\end{array}$ \\
\hline $\begin{array}{l}\text { Real-time PCR or quantitative PCR } \\
\text { (qPCR/RT-qPCR) }\end{array}$ & $\begin{array}{l}\text { Quantitative } \\
\text { Sensitive } \\
\text { Specific } \\
\text { Can be multiplexed } \\
\text { Results can be obtained in } 2-4 \mathrm{~h}\end{array}$ & $\begin{array}{l}\text { Does not differentiate between infectious and } \\
\text { noninfectious viruses } \\
\text { Prone to PCR inhibition }\end{array}$ \\
\hline $\begin{array}{l}\text { Long-target-region PCR } \\
\text { (LTR-PCR) }\end{array}$ & May provide information on viral infectivity & May reduce detection sensitivity \\
\hline Digital PCR & $\begin{array}{l}\text { Does not require standard curve } \\
1-2 \text { orders more sensitive than } \mathrm{qPCR} \\
\text { Less prone to PCR inhibition }\end{array}$ & $\begin{array}{l}\text { Platform is expensive } \\
\text { Limited dynamic range of detection } \\
\text { Limited number of samples can be processed } \\
\text { compared to qPCR format }\end{array}$ \\
\hline $\begin{array}{l}\text { Nucleic acid sequence-based } \\
\text { amplification }\end{array}$ & $\begin{array}{l}\text { Rapid compared to PCR } \\
\text { Can be multiplexed } \\
\text { Does not require a thermal cycler } \\
\text { Portable and easy-to-use detection method; suitable } \\
\text { for a laboratory with basic instruments }\end{array}$ & $\begin{array}{l}\text { Sample pretreatment is required } \\
\text { RNA handling may require attention }\end{array}$ \\
\hline Microarray & $\begin{array}{l}\text { Multiple viral targets can be detected } \\
\text { Powerful diagnostic tool }\end{array}$ & $\begin{array}{l}\text { Assay designing requires significant } \\
\text { bioinformatics knowledge } \\
\text { Random amplification is required } \\
\text { Sensitivity is questionable for environmental } \\
\text { waters } \\
\text { Nonquantitative }\end{array}$ \\
\hline
\end{tabular}

can lead to death when fulminant hepatitis associated with chronic liver disease occurs. In addition, it can lead to extrahepatic complications, including pancreatitis, vasculitis, and glomerulonephritis (151).

While the mortality rate from HAV is generally low, repair of liver damage is a slow process that can keep patients disabled for more than 6 weeks. The estimated mortality rate is $0.1 \%$ in children $<15$ years old, $0.3 \%$ for adults 15 to 39 years old, and about $2.1 \%$ in adults $\geq 40$ years old $(30,161)$. After infection, HAV can continue to be excreted in feces for 6 months. The concentration of HAV may range from $10^{6} \mathrm{GC} / \mathrm{ml}$ in serum to more than $10^{8} \mathrm{GC} / \mathrm{ml}$ in stool (160).
HAV has a global distribution and is a major worldwide cause of acute viral hepatitis, with approximately 1.4 million clinical cases reported each year globally $(161,162)$. However, the highest endemicity of HAV occurs in regions with poor sanitation and wastewater treatment practices, particularly in countries of South Asia, Africa, Central and South America, and the Middle East. In these regions the seroprevalence of HAV immunoglobulin $G$ antibodies reaches $90 \%$ in adults, and most children have been infected by 10 years of age (162-164). In regions of intermediate endemicity, including North America, western Europe, Australia, and Japan, 50 to $60 \%$ of adults and 20 to $30 \%$ of 10 -year-old children are 
infected with HAV. In regions with low endemicity, such as some northern European countries, better hygiene conditions and socioeconomic status have led to a decrease in infection rates during childhood $(155,162)$.

Most HAV infections are transmitted via the fecaloral route (about 95\%), mainly through ingestion of contaminated water and food $(151,160,162,165,166)$. In recent years, this virus has been detected in drinking water, surface water, groundwater, and treated and untreated wastewater in many countries (Table 2).

This virus has been shown to be resistant to several water treatment processes, including concentrations of free residual chlorine of 0.5 to $1.5 \mu \mathrm{g} / \mathrm{ml}$ for $1 \mathrm{~h}$, at temperatures between 60 and $80^{\circ} \mathrm{C}$ for $1 \mathrm{~h}$, freeze/thaw, relatively low moisture $( \pm 25 \%$ for 7 days $)$, and low $\mathrm{pH}$ (pH 1) (160). Several studies have shown the presence of HAV in influent samples but also in a considerable number of treated effluent samples (Table 2).

The foods most commonly associated with the transmission of HAV are shellfish, vegetables, and fruits. However, bivalves (shellfish) are more easily contaminated with these viruses due to filtration of large amounts of water during their natural feeding (162, 167). Polo et al. (167) reported that reverse transcriptase quantitative PCR (qPCR) analyses indicated that $\sim 10 \%$ of bivalve samples obtained from 10 harvesting areas in estuarine inlets on the coast of Galicia, Spain, an important bivalve production area in Europe, contained HAV and NoV in 2011 to 2012.

\section{Hepatitis E}

HEV is a small, nonenveloped, single-stranded RNA virus of the genus Hepevirus in the family Hepeviridae. The virions are spherical particles with a diameter of 27 to $34 \mathrm{~nm}(168,169)$. HEVs infecting humans are divided into four genotypes (genotypes 1 to 4 ), with several subgenotypes (170). Genotypes 1 and 2 infect only humans and are responsible for many outbreaks, mainly in developing countries with poor sanitation conditions $(170,171)$. Genotypes 3 and 4 infect humans and other animals. Genotype 1 is prevalent in South Asia, Central Asia, and North Africa; genotype 2, in Mexico and West Africa; genotype 3, in the Americas, Europe, and Japan; and genotype 4, in China and Southeast Asia (168, 171, 172). In addition to waterborne transmission, HEV can be transmitted through ingestion of contaminated food, transfusions with contaminated blood, and vertical transmission (maternal-fetal) (168, 172-175).

After entering the body, the virus mainly targets the liver. It accumulates in bile and reaches the intestine through the bile duct, being found in the feces of the host about two weeks after initial infection (176). The incubation period of the HEV ranges from 15 to 60 days, but depending on the genotype in question, it may take longer, reaching 6 months for genotype 3 (174). The infectious dose of HEV in humans is not known (159).

The symptoms of acute infection caused by HEV are similar to those of HAV. After the virus enters the body, there is an increase in liver enzymes, such as alanine aminotransferase, aspartate transaminase, and gammaglutamyl transpeptidase. The resulting symptoms include jaundice, vomiting, loss of appetite, fatigue, fever, darkened urine, hepatalgia, and hepatomegaly $(175,177)$. $\mathrm{HEV}$ infection may also be associated with neurological complications, notably Guillain-Barré syndrome, neuralgic amyotrophy, inflammatory polyradiculopathy, ataxia/ encephalitis, and peripheral neuropathy $(178,179)$.

The mortality rate associated with HEV is about $2 \%$ in the general population, but in pregnant women, the mortality rate is much higher, reaching $20 \%$ due to fulminant hepatic failure $(177,180)$. The number of reported HEV infections is probably an underestimation of the actual worldwide burden (170). In 2005, it was estimated that 20.1 million people were infected with HEV (genotypes 1 and 2), resulting in 3.4 million symptomatic cases, 70,000 deaths, and 3,000 stillborn infants (171).

In regions of endemicity, the seroprevalence rates of antibodies to HEV range from 15 to $16 \%$. The peak of incidence of HEV occurs in young people between 15 and 35 years of age. In countries with a low incidence of $\mathrm{HEV}$, the prevalence of antibodies to HEV varies from $3 \%$ in Tokyo, Japan, $3.2 \%$ in central France, $7.3 \%$ in Catalonia, Spain, $16.6 \%$ in southwest France, $16 \%$ in southwest England, $20.2 \%$ in Portugal (181), to $21.3 \%$ in U.S. blood donors (180). Initially, it was thought that HEV was not an important public health threat in industrialized countries because infections were generally reported in people who had traveled to areas where the virus is endemic. However, in recent years, a number of sporadic cases or small clusters of cases have been reported in developed countries in the absence of travel to countries of HEV endemicity, suggesting the existence of HEV reservoirs in these areas. Sporadic reports of cases have emerged in the United States, Europe (United Kingdom, France, the Netherlands, Austria, Spain, Italy, and Greece), and developed Asia-Pacific countries (Japan, Taiwan, Hong Kong, and Australia) $(182,183)$.

$\mathrm{HEV}$ is the only enteric virus with a large animal reservoir, which includes domestic animals such as swine, cattle, goats, and rodents (30, 175, 178, 184). HEV is mainly transmitted by the fecal-oral route, through ingestion of contaminated or insufficiently 
treated water $(168,172-174,184)$, and in undercooked pork products $(185)$ (Table 1). This virus has been detected in environmental water and treated and untreated wastewater from several countries (Table 2).

\section{ENTERIC VIRUS DETECTION METHODS}

Virus concentrations in water systems are expected to increase with escalating frequencies of flooding and sewage contamination events, in large part due to changes in extreme weather and climate change combined with shortages of potable water sources. The standard methods of detection of infectious viruses in water require the use of susceptible cell lines within which the viruses can propagate and produce cytopathic effects. However, these methods are time-consuming and are not suitable for the detection of some nonculturable/noncytopathic enteric viruses; e.g., several of these viruses cannot be grown easily (e.g., adenovirus serotypes 40 and 41 ) or at all (e.g., HAV) in cell culture $(186,187)$. In the case of $\mathrm{NoV}$, recent advances have been made for its cultivation (188).

Recently, there has been an investment in developing molecular methods for microbiological risk assessment through the detection and quantification of viral nucleic acids in food and water samples $(\underline{56}, \underline{189}, \underline{190})$. Due to their high sensitivity, these methods also overcome the problems of low density of viruses in water samples, making the virus detection not strictly dependent on concentration methods to detect pathogens. Real-time qPCR (RT-qPCR) has been increasingly used for microbiological risk assessment through the detection and quantification of viral nucleic acids in food and water samples $(\underline{56}, \underline{189}, 190)$.

Aside from HAdV having a DNA genome, most waterborne viruses with significant public health implications have RNA genomes. The evolution of the PCR method greatly increased the capacity to detect pathogenic viruses in the environment, with high sensitivity and specificity. However, this method has the limitation of not allowing the evaluation of virus viability and infectivity, defined as the capacity of the virus to infect host cells and to use their resources to produce new infectious virus particles. This aspect is important in assessing and understanding the risks to public health, because even if viral nucleic acids are detected by the PCR technique in water samples, they may not be able to infect human cells (191193). Based on statistical correlations between genome copy numbers and infectious enteric viral particles in wastewater samples, Donia et al. (194) proposed a cutoff value of $200 \mathrm{GC} /$ liter to be used as an indication of $\mathrm{EV}$ survival in environmental monitoring (194).
Table 3 summarizes the currently used methods for detection/quantification of virus, as well as the advantages and disadvantages of each of them (based on reference 195).

\section{CONCLUSIONS}

\section{Paradigm Shift Due to Climate Changes}

The United Nations Intergovernmental Panel on Climate Change (IPCC) has forecasted that carbon dioxide emissions will result in an increase in the frequency, duration, and severity of extreme weather events (https://www.ipcc.ch/). Severe droughts, heatwaves, floods, and destructive storms are expected with growing intensity and frequency. These often compromise the integrity of infrastructure built to supply homes with commodities and to drain and treat our liquid wastes (196). Included in these extreme weather scenarios are the scarcity of potable water and the possible crosscontamination between inlet and outlet water systems (http://www.unwater.org/water-facts/scarcity/).

To mitigate climate change and global warming effects and to protect water sources and human health, the United Nations Framework Convention on Climate Change agreed in 2016 to maintain the increase in global temperature of "well under $2^{\circ} \mathrm{C}$ " above the preindustrial era. This covenant, which became known as the Paris agreement, aims to strengthen global responses to threats of climate change and to increase the ability of countries to deal with the impacts of climate change (https://unfccc.int/process-and-meetings/the-paris -agreement/the-paris-agreement). While these goals are ongoing, the rise in global temperature has been melting ice in glaciers, resulting in a global sea level rise of $\sim 23 \mathrm{~cm}$ since 1880 according to the U.S. Environmental Protection Agency's 2016 report (197), and the rate of sea rise is accelerating. Countries located away from the poles will see their territorial limits regress and will suffer from salt introgression, a phenomenon where potable water becomes contaminated by invading sea water, rendering it useless unless desalinated. The WHO recommends that countries develop drinking water safety plans for preparedness against depletion of potable water sources, and these are currently in implementation throughout Europe and the United States (40).

\section{New Challenges for Water Management and Alternative Sources}

Currently, there is an increasing need for alternative water sources due in large part to a shortage of potable water supplies. Some of the alternative water sources are 
located far underground, where viral particles are small enough (under $100 \mathrm{~nm}$ ) to pass through soils and sediments without being adsorbed, thus contaminating these water sources. Future drinking water safety measures need to be modified to include particles that readily indicate the actual contamination of water, rather than fecal indicator organisms.

In times of scarcity, water reuse programs will face strong demand from agriculture, industrial, and urban sectors (198). Taking into account that most pathogenic viruses are also resistant to several of the most commonly used water treatment technologies (disinfection,

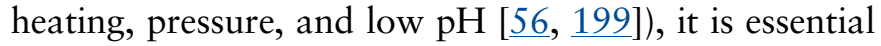
that the treatment of water for human consumption or water reuse be effective and regulated (200). However, some studies indicate that these treatments are sometimes not completely effective in eliminating the enteric viruses discussed here, either in drinking water or wastewater $(\underline{38}, 56,189,190,201)$. Moreover, about $90 \%$ of all wastewater is released into the environment without complete disinfection. This represents a risk of exposure to these viruses, not only through direct consumption of water, but also through indirect pathways such as recreation or the consumption of vegetables, bivalves, or animal meat that comes into contact with contaminated water $(167, \underline{187}, \underline{189})$.

Despite the fact that there has been great investment and advancement in water/wastewater treatment technologies for use in developing countries, these solutions are not available for every community and in every country. This leads to situations where populations depend on untreated surface water for their immediate water needs, resulting in waterborne outbreaks which remain a significant threat to human health worldwide (202). The underreporting of outbreaks related to enteric viruses, mostly in countries where these viruses are not endemic, hinders the establishment of a universal screening system to track the distribution and frequency of these outbreaks.

In this review, we have presented the main enteric viruses that we believe should start being used as additional fecal indicators in water quality assessment and monitoring. We can monitor for viruses that cause illness, surrogates of viruses, and/or viruses that indicate the possible presence of human fecal waste. The presence and prevalence of several of the viruses addressed here in surface and groundwater intended for human consumption raises a potential health risk. Despite the shortcomings of FIB monitoring, it can be useful, particularly for significant sewage contamination events. However, since enteric viruses are resistant to WWTP treatments and their concentrations can be low but highly variable in treated wastewater, more research is needed on the use of indicator viruses as proxy for enteric viruses. More data comparing the fates of FIB and enteric viruses in various stages of wastewater treatment processes are also required to support their application for regulatory use.

\section{ACKNOWLEDGMENTS}

Thanks for financial support are due to CESAM (UID/AMB/ 50017/2019) and FCT/MCTES through national funds and for the cofunding by the FEDER within the PT2020 Partnership Agreement and Compete 2020. This research was partially supported by Câmara Municipal de Lisboa, EPAL (Empresa Portuguesa das Águas Livres) and the Foundation for Science and Technology (FCT) Portugal for the Ph.D. grant to D. Salvador (PDE/BDE/114582/2016).

\section{REFERENCES}

1. Coumou D, Rahmstorf S. 2012. A decade of weather extremes. Nat Clim Change 2:491-496.

2. Wikipedia contributors. Accessed 7 February 2020. 2010 Madeira floods and mudslides. https://en.wikipedia.org/wiki/2010_Madeira _floods_and_mudslides.

3. Romão D, Abreu R, Calado G, Freitas F, Rodrigues P, Ferreira C, Campos A, Temtem Rita, Freitas C, Andrade C, Prada S, Figueira C, Brandão J. 2017. Madeira 2010: aftermath of flashfloods and mudslides on bathing water quality indicators and on sand microbial levels. PanEuropean Symposium Water and Sanitation Safety Planning and Extreme Weather Events, Bilthoven, Nederlands.

4. Kauppinen A, Pitkänen T, Al-Hello H, Maunula L, Rimhanen-Finne R, Miettinen I. 2018. Two drinking water outbreaks caused by sapovirus in Finland. 6th Food and Environmental Virology Conference, Tempe, AZ. 5. Roca MA, Brown, RS, Solo-Gabriele HM. 2019. Fecal indicator bacteria levels at beaches in the Florida Keys after Hurricane Irma. Marine Pollut Bull 138:266-273.

6. Tang Y, Wu S, Miao X, Pollard SJT, Hrudey SE. 2013. Resilience to evolving drinking water contamination risks: a human error prevention perspective. J Cleaner Prod 57:228-237.

7. Fujioka RS, Solo-Gabriele HM, Byappanahalli MN, Kirs M. 2015. US recreational water quality criteria: a vision for the future. Int J Environ Res Public Health 12:7752-7776.

8. USEPA. 2007. Report of the Experts Scientific Workshop on Critical Research Needs for the Development of New or Revised Recreational Water Quality Criteria. EPA 823-R-07-006, United States Environmental Protection Agency, Washington, DC.

9. Byappanahalli MN, Nevers MB, Korajkic A, Staley ZR, Harwood VJ. 2012. Enterococci in the environment. Microbiol Mol Biol Rev 76:685706.

10. Ishii S, Sadowsky M. 2008. Escherichia coli in the environment: implications for water quality and human health. Microbes Environ 23:101-108.

11. Wright ME, Solo-Gabriele HM, Elmir S, Fleming LE. 2009. Microbial load from animal feces at a recreational beach. Marine Pollut Bull 58:1649-1656.

12. Wade TJ, Calderon RL, Sams E, Beach M, Brenner KP, Williams AH, Dufour AP. 2006. Rapidly measured indicators of recreational water quality are predictive of swimming-associated gastrointestinal illness. Environ Health Perspect 114:24-28.

13. McQuaig SM, Scott TM, Lukasik JO, Paul JH, Harwood VJ. 2009. Quantification of human polyomaviruses JC virus and BK virus by TaqMan 
quantitative PCR and comparison to other water quality indicators in water and fecal samples. Appl Environ Microbiol 75:3379-3388.

14. Hughes B, Beale DJ, Dennis PG, Cook S, Ahmed W. 2017. Cross-comparison of human wastewater-associated molecular markers in relation to fecal indicator bacteria and enteric viruses in recreational beach waters. Appl Environ Microbiol. 83:e0028-17.

15. Rusiñol M, Fernandez-Cassi X, Hundesa A, Vieira C, Kern A, Eriksson, Ziros P, Kay D, Miagostovich M, Vargha M, Allard A, Vantarakis A, Wyn-Jones P, Bofill-Mas S, Girones R. 2014. Application of human and animal viral microbial source tracking tools in fresh and marine waters from five different geographical areas. Water Res 59:119-129.

16. Symonds E, Sinigalliano C, Gidley M, Ahmed W, McQuaig SM, Breitbart M. 2016. Fecal pollution along the southeastern coast of Florida and insight into the use of pepper mild mottle virus as an indicator. J Appl Microbiol 121:1469-1481.

17. Stachler E, Kelty C, Sivaganesan M, Li X, Bibby K, Shanks OC. 2017 Quantitative CrAssphage PCR assays for human fecal pollution measurement. Environ Sci Technol 51:9146-9154.

18. Ahmed W, Goonetilleke A, Gardner T. 2010. Human and bovine adenoviruses for the detection of source-specific fecal pollution in coastal waters in Australia. Water Res 44:4662-4673.

19. Wolf S, Hewitt J, Greening GE. 2010. Viral multiplex quantitative PCR assays for tracking sources of fecal contamination. Appl Environ Microbiol 76:1388-1394.

20. Rusiñol M, Fernandez-Cassi X, Hundesa A, Vieira C, Kern A, Eriksson I, Ziros P, Kay D, Miagostovich M, Vargha M, Allard A, Vantarakis A, Wyn-Jones P, Bofill-Mas S, Girones R. 2014. Application of human and animal viral microbial source tracking tools in fresh and marine waters from five different geographical areas. Water Res 59:119-129.

21. Cai L, Zhang T. 2013. Detecting human bacterial pathogens in wastewater treatment plants by a high-throughput shotgun sequencing technique. Environ Sci Technol 47:5433-5441.

22. Ahmed W, O'Dea C, Masters N, Kuballa A, Marinoni O, Katouli M. 2019. Marker genes of fecal indicator bacteria and potential pathogens in animal feces in subtropical catchments. Sci Total Environ 656:1427-1435. 23. Jebri S, Muniesa M, Jofre J. 2017. General and host-associated bacteriophage indicators of fecal pollution. In Rose JB, Jiménez-Cisneros B (eds), Global Water Pathogen Project. http://www.waterpathogens.org. Part 2 Indicators and Microbial Source Tracking Markers. http:// www.waterpathogens.org/book/coliphage. Michigan State University, E. Lansing, MI, UNESCO. https://doi.org/10.14321/waterpathogens.7.

24. Wu J, Long SC, Das D, Dorner SM. 2011. Are microbial indicators and pathogens correlated? A statistical analysis of 40 years of research. $J$ Water Health 9:265-278.

25. Hoff JC, Akin EW. 1986. Microbial resistance to disinfectants: mechanisms and significance. Environ Health Pers 69:7-13.

26. Bonadonna L, La Rosa G. 2019. A review and update on waterborne viral diseases associated with swimming pools. Int J Environ Res Public Health 16:166.

27. McDonnell G, Russell AD. 1999. Antiseptics and disinfectants: activity, action, and resistance. Clin Microbiol Rev 12:147-179.

28. Cromeans TL, Kahler AM, Hill VR. 2010. Inactivation of adenoviruses, enteroviruses, and murine norovirus in water by free chlorine and monochloramine. Appl Environ Microbiol 76:1028-1033.

29. Tree JA, Adams MR, Lees DN. 2003. Chlorination of indicator bacteria and viruses in primary sewage effluent. Appl Environ Microbiol 69:2038-2043.

30. Funari E, Kistemann T, Herbst S, Rechenburg A. 2011. Technical Guidance on Water-Related Disease Surveillance. World Health Organization Europe, Copenhagen, Denmark.

31. Stanwell-Smith R. 2003. Classification of water-related disease, p 124. In Water and Health. Encyclopedia of Life Support Systems (EOLSS).
UNESCO - Encyclopedia Life Support Systems (UNESCO-EOLSS), Paris, France.

32. Hutton G. 2012. Global Costs and Benefits of Drinking-Water Supply and Sanitation Interventions to Reach the MDG Target and Universal Coverage. World Health Organization, Geneva, Switzerland.

33. UNICEF, WHO. 2017. Progress on Drinking Water, Sanitation and Hygiene: 2017 Update and SDG Baselines. World Health Organization (WHO)/United Nations Children's Fund (UNICEF), Geneva, Switzerland.

34. Dorfman M, Stoner N, Merkel M. 2004. Swimming in sewage. Natural Resources Defense Council and the Environmental Integrity. http://environ mentalintegrity.org/pdf/publications/Swimming_in_Sewage_REPORT.pdf. 35. Ramírez-Castillo FY, Loera-Muro A, Jacques M, Garneau P, AvelarGonzález FJ, Harel J, Guerrero-Barrera AL. 2015. Waterborne pathogens: detection methods and challenges. Pathogens 4:307-334.

36. Campos CJ, Avant J, Lowther J, Till D, Lees DN. 2016. Human norovirus in untreated sewage and effluents from primary, secondary and tertiary treatment processes. Water Res 103:224-232.

37. Guerrero-Latorre L, Gonzales-Gustavson E, Hundesa A, Sommer R, Rosina G. 2016. UV disinfection and flocculation-chlorination sachets to reduce hepatitis $\mathrm{E}$ virus in drinking water. Int J Hygiene Environ Health 219:405-411.

38. Kokkinos P, Mandilara G, Nikolaidou A, Velegraki A, Theodoratos P, Kampa D, Blougoura A, Christopoulou A, Smeti E, Kamizoulis G, Vantarakis A, Mavridou A. 2015. Performance of three small-scale wastewater treatment plants. A challenge for possible reuse. Environ Sci Pollut Res Int 22:17744-17752.

39. Chigor VN, Okoh AI. 2012. Quantitative RT-PCR detection of hepatitis A virus, rotaviruses and enteroviruses in the Buffalo River and source water dams in the Eastern Cape Province of South Africa. Int J Environ Res Public Health 9:4017-4032.

40. WHO. 2017. Guidelines for Drinking-Water Quality, 4th ed, incorporating the 1st addendum, p 1-541. Geneva, Switzerland.

41. Macy JT, Quick RE. 2009. Transmission and prevention of waterrelated diseases, p 104-107. In Grabow W (ed), Water and Health, vol I. EOLSS Publications. UNESCO - Encyclopedia Life Support Systems (UNESCO-EOLSS), Paris, France.

42. Buckwalter SP, Teo R, Espy MJ, Sloan LM, Smith TF, Pritt BS. 2012. Real-time qualitative PCR for 57 human adenovirus types from multiple specimen sources. J Clin Microbiol 50:766-771.

43. Mangel WF, San Martín C. 2014. Structure, function and dynamics in adenovirus maturation. Viruses 6:4536-4570.

44. Russell WC. 2009. Adenoviruses: update on structure and function. $J$ Gen Virol 90:1-20.

45. Elhag WI, Saeed HA, Omer el FE, Ali AS. 2013. Prevalence of rotavirus and adenovirus associated with diarrhea among displaced communities in Khartoum, Sudan. BMC Infect Dis 13:209.

46. Gray GC, McCarthy T, Lebeck MG, Schnurr DP, Russell KL, Kajon AE, Landry ML, Leland DS, Storch GA, Ginocchio CC, Robinson CC, Demmler GJ, Saubolle MA, Kehl SC, Selvarangan R, Miller MB, Chappell JD, Zerr DM, Kiska DL, Halstead DC, Capuano AW, Setterquist SF, Chorazy ML, Dawson JD, Erdman DD. 2007. Genotype prevalence and risk factors for severe clinical adenovirus infection, United States 20042006. Clin Infect Dis 45:1120-1131.

47. Zlateva KT, Maes P, Rahman M, Van Ranst M. 2005. Chromatography paper strip sampling of enteric adenoviruses type 40 and 41 positive stool specimens. Virol J 2:6.

48. Crabtree KD, Gerba CP, Rose JB, Haas CN. 1997. Waterborne adenovirus: a risk assessment. Water Sci Technol 35:1-6.

49. Cruz JR, Cáceres P, Cano F, Flores J, Bartlett A, Torún B. 1990. Adenovirus types 40 and 41 and rotaviruses associated with diarrhea in children from Guatemala. J Clin Microbiol 28:1780-1784.

50. Hendrix RM, Lindner JL, Benton FR, Monteith SC, Tuchscherer MA, Gray GC, Gaydos JC. 1999. Large, persistent epidemic of adenovirus type 
4-associated acute respiratory disease in U.S. army trainees. Emerg Infect Dis 5:798-801.

51. Kapikian AZ, Wyatt RG. 1992. Viral gastrointestinal infections, p 667-676. In Feigin RD, Cherry JF (ed), Textbook of Pediatric Infectious Diseases, vol. 1, 3rd ed. Elsevier, Ontario, Canada.

52. Jiang S, Noble R, Chu W. 2001. Human adenoviruses and coliphages in urban runoff-impacted coastal waters of southern California. Appl Environ Microbiol 67:179-184.

53. Couch RB, Cate TR, Douglas RG, Jr, Gerone PJ, Knight V. 1966. Effect of route of inoculation on experimental respiratory viral disease in volunteers and evidence for airborne transmission. Bacteriol Rev 30:517529.

54. Aw TG, Gin KY. 2010. Environmental surveillance and molecular characterization of human enteric viruses in tropical urban wastewaters. J Appl Microbiol 109:716-730.

55. Iaconelli M, Muscillo M, Della Libera S, Fratini M, Meucci L, De Ceglia M, Giacosa D, La Rosa G. 2017. One-year surveillance of human enteric viruses in raw and treated wastewaters, downstream river waters, and drinking waters. Food Environ Virol 9:79-88.

56. Adefisoye MA, Nwodo UU, Green E, Okoh AI. 2016. Quantitative PCR detection and characterisation of human adenovirus, rotavirus and hepatitis A virus in discharged effluents of two wastewater treatment facilities in the Eastern Cape, South Africa. Food Environ Virol 8:262-274. 57. Carducci A, Verani M. 2013. Effects of bacterial, chemical, physical and meteorological variables on virus removal by a wastewater treatment plant. Food Environ Virol 5:69-76.

58. Katayama H, Haramoto E, Oguma K, Yamashita H, Tajima A, Nakajima H, Ohgaki S. 2008. One-year monthly quantitative survey of noroviruses, enteroviruses, and adenoviruses in wastewater collected from six plants in Japan. Water Res 42:1441-1448.

59. Thurston-Enriquez JA, Haas CN, Jacangelo J, Gerba CP. 2003. Chlorine inactivation of adenovirus type 40 and feline calicivirus. Appl Environ Microbiol 69:3979-3985.

60. Fong TT, Lipp EK. 2005. Enteric viruses of humans and animals in aquatic environments: health risks, detection, and potential water quality assessment tools. Microbiol Mol Biol Rev 69:357-371.

61. Lu QB, Tong YG, Wo Y, Wang HY, Liu EM, Gray GC, Liu W, Cao WC. 2014. Epidemiology of human adenovirus and molecular characterization of human adenovirus 55 in China, 2009-2012. Influenza Other Respir Viruses 8:302-308.

62. Sinclair RG, Jones EL, Gerba CP. 2009. Viruses in recreational waterborne disease outbreaks: a review. J Appl Microbiol 107:1769-1780.

63. Choi S, Jiang SC. 2005. Real-time PCR quantification of human adenoviruses in urban rivers indicates genome prevalence but low infectivity. Appl Environ Microbiol 71:7426-7433.

64. McBride GB, Stott R, Miller W, Bambic D, Wuertz S. 2013. Discharge-based QMRA for estimation of public health risks from exposure to stormwater-borne pathogens in recreational waters in the United States. Water Res 47:5282-5297.

65. Vergara GG, Rose JB, Gin KY. 2016. Risk assessment of noroviruses and human adenoviruses in recreational surface waters. Water Res 103:276-82.

66. Bae S, Wuertz S. 2012. Survival of host-associated Bacteroidales cells and their relationship with Enterococcus spp., Campylobacter jejuni, Salmonella enterica serovar Typhimurium, and adenovirus in freshwater microcosms as measured by propidium monoazide-quantitative PCR. Appl Environ Microbiol 78:922-932.

67. Eifan SA. 2013. Enteric viruses and aquatic environment. Internet J Microbiol 12:1-7.

68. Bruu AL. 2002. Enteroviruses: polioviruses, coxsackieviruses, echoviruses and newer enteroviruses, p 44-45. In Haaheim LR, Pattison JR, Whitley RJ (ed), A Practical Guide to Clinical Virology, 2nd ed. John Wiley \& Sons, Ltd., Chichester, United Kingdom.
69. Holm-Hansen CC, Midgley SE, Fischer TK. 2016. Global emergence of enterovirus D68: a systematic review. Lancet Infect Dis 16:64-75. 70. Solomon T, Lewthwaite P, Perera D, Cardosa MJ, McMinn P, Ooi MH. 2010. Virology, epidemiology, pathogenesis, and control of enterovirus 71. Lancet Infect Dis 10:778-790.

71. Muehlenbachs A, Bhatnagar J, Zaki SR. 2015. Tissue tropism, pathology and pathogenesis of enterovirus infection. J Pathol 235:217228.

72. Palminha P, Ribeiro C, Roque C, Vinagre E. 2015. Vigilância laboratorial da infeção a Enterovirus entre 2010 e 2013. Bol Epidemiol Observações 5:19-21.

73. Chang PC, Chen SC, Chen KT. 2016. The current status of the disease caused by enterovirus 71 infections: epidemiology, pathogenesis, molecular epidemiology, and vaccine development. Int J Environ Res Public Health 13:29-34.

74. Symonds EM, Verbyla ME, Lukasik JO, Kafle RC, Breitbart M, Mihelcic JR. 2014. A case study of enteric virus removal and insights into the associated risk of water reuse for two wastewater treatment pond systems in Bolivia. Water Res 65:257-270.

75. Clarke IN, Estes MK, Green KY, Hansman GS, Knowles NJ, Koopmans M, Matson DO, Meyers G, Neill J, Radford A, Smith AW, Studdert M, Thiel H-J., Vinjé J. 2012. Caliciviridae, p 977-985. In King AMQ, Adams MJ, Carstens EB, Lefkowitz EJ (eds), Virus Taxonomy: Classification and Nomenclature of Viruses. 9th report of the International Committee on Taxonomy of Viruses. Elsevier Academic Press, San Diego, CA.

76. Green K. 2013. Caliciviridae: the noroviruses, p 583-609, In Knipe DM, Howley PM(ed), Fields Virology, vol 1, 6th ed. Lippincott Williams \& Wilkins, Philadelphia, PA.

77. Kroneman A, Vega E, Vennema H, Vinjé J, White PA, Hansman G, Green K, Martella V, Katayama K, Koopmans M. 2013. Proposal for a unified norovirus nomenclature and genotyping. Arch Virol 158:20592068.

78. Vinjé J. 2015. Advances in laboratory methods for detection and typing of norovirus. J Clin Microbiol 53:373-381.

79. Zheng DP, Ando T, Fankhauser RL, Beard RS, Glass RI, Monroe SS. 2006. Norovirus classification and proposed strain nomenclature. Virology 346:312-323.

80. Bartsch SM, Lopman BA, Ozawa S, Hall AJ, Lee BY. 2016. Global economic burden of norovirus gastroenteritis. PLoS One 11:e0151219.

81. Patel MM, Widdowson MA, Glass RI, Akazawa K, Vinjé J, Parashar UD. 2008. Systematic literature review of role of noroviruses in sporadic gastroenteritis. Emerg Infect Dis 14:1224-1231.

82. Graham DY, Jiang X, Tanaka T, Opekun AR, Madore HP, Estes MK. 1994. Norwalk virus infection of volunteers: new insights based on improved assays. J Infect Dis 170:34-43.

83. Phillips G, Tam CC, Rodrigues LC, Lopman B. 2010. Prevalence and characteristics of asymptomatic norovirus infection in the community in England. Epidemiol Infect 138:1454-1458.

84. Harris JP, Edmunds WJ, Pebody R, Brown DW, Lopman BA. 2008. Deaths from norovirus among the elderly, England and Wales. Emerg Infect Dis 14:1546-1552.

85. Hutson AM, Atmar RL, Estes MK. 2004. Norovirus disease: changing epidemiology and host susceptibility factors. Trends Microbiol 12:279287.

86. Payne DC, Vinjé J, Szilagyi PG, Edwards KM, Staat MA, Weinberg GA, Hall CB, Chappell J, Bernstein DI, Curns AT, Wikswo M, Shirley SH, Hall AJ, Lopman B, Parashar UD. 2013. Norovirus and medically attended gastroenteritis in U.S. children. N Engl J Med 368:1121-1130.

87. Siebenga JJ, Vennema H, Zheng DP, Vinjé J, Lee BE, Pang XL, Ho EC, Lim W, Choudekar A, Broor S, Halperin T, Rasool NB, Hewitt J, Greening GE, Jin M, Duan ZJ, Lucero Y, O'Ryan M, Hoehne M, Schreier E, Ratcliff RM, White PA, Iritani N, Reuter G, Koopmans M. 2009. 
Norovirus illness is a global problem: emergence and spread of norovirus GII.4 variants, 2001-2007. J Infect Dis 200:802-812.

88. Tian G, Jin M, Li H, Li Q, Wang J, Duan ZJ. 2014. Clinical characteristics and genetic diversity of noroviruses in adults with acute gastroenteritis in Beijing, China in 2008-2009. J Med Virol 86:1235-1242. 89. Ahmed SM, Hall AJ, Robinson AE, Verhoef L, Premkumar P, Parashar UD, Koopmans M, Lopman BA. 2014. Global prevalence of norovirus in cases of gastroenteritis: a systematic review and metaanalysis. Lancet Infect Dis 14:725-730.

90. Pires SM, Fischer-Walker CL, Lanata CF, Devleesschauwer B, Hall AJ, Kirk MD, Duarte AS, Black RE, Angulo FJ. 2015. Aetiologyspecific estimates of the global and regional incidence and mortality of diarrhoeal diseases commonly transmitted through food. PLoS One 10: e0142927.

91. Ahmed SM, Lopman BA, Levy K. 2013. A systematic review and meta-analysis of the global seasonality of norovirus. PLoS One 8:e75922. 92. Lanata CF, Fischer-Walker CL, Olascoaga AC, Torres CX, Aryee MJ, Black RE. 2013. Global causes of diarrheal disease mortality in children $<5$ years of age: a systematic review. PLoS One 8:e72788.

93. Lopman BA, Steele D, Kirkwood CD, Parashar UD. 2016. The vast and varied global burden of norovirus: prospects for prevention and control. PLoS Med 13:e1001999.

94. Teunis PF, Moe CL, Liu P, Miller SE, Lindesmith L, Baric RS, Le Pendu J, Calderon RL. 2008. Norwalk virus: how infectious is it? J Med Virol 80:1468-1476.

95. Atmar RL, Opekun AR, Gilger MA, Estes MK, Crawford SE, Neill FH, Ramani S, Hill H, Ferreira J, Graham DY. 2014. Determination of the $50 \%$ human infectious dose for Norwalk virus. J Infect Dis 209:10161022 .

96. Kirby AE, Teunis PF, Moe CL. 2014. Two human challenge studies confirm high infectivity of Norwalk virus. J Infect Dis. https://doi.org /10.1093/infdis/jiu585.

97. Kambhampati A, Payne DC, Costantini V, Lopman BA. 2016. Host genetic susceptibility to enteric viruses: a systematic review and metaanalysis. Clin Infect Dis 62:11-18.

98. Pang XL, Preiksaitis JK, Lee BE. 2014. Enhanced enteric virus detection in sporadic gastroenteritis using a multi-target real-time PCR panel: a one-year study. J Med Virol 86:1594-601.

99. Parrino TA, Schreiber DS, Trier JS, Kapikian AZ, Blacklow NR. 1977. Clinical immunity in acute gastroenteritis caused by Norwalk agent. N Engl J Med 297:86-89.

100. Fankhauser RL, Monroe SS, Noel JS, Humphrey CD, Bresee JS, Parashar UD, Ando T, Glass RI. 2002. Epidemiologic and molecular trends of "Norwalk-like viruses" associated with outbreaks of gastroenteritis in the United States. J Infect Dis 186:1-7.

101. Rockx B, De Wit M, Vennema H, Vinjé J, De Bruin E, Van Duynhoven Y, Koopmans M. 2002. Natural history of human calicivirus infection: a prospective cohort study. Clin Infect Dis 35:246-253.

102. Matsui SM, Greenberg HB. 2000. Immunity to calicivirus infection. J Infect Dis 181:S331-335.

103. Johnson PC, Mathewson JJ, DuPont HL, Greenberg HB. 1990. Multiple-challenge study of host susceptibility to Norwalk gastroenteritis in US adults. J Infect Dis 161:18-21.

104. Wyatt RG, Greenberg HB, Dalgard DW, Allen WP, Sly DL, Thornhill TS, Chanock RM, Kapikian AZ. 1978. Experimental infection of chimpanzees with the Norwalk agent of epidemic viral gastroenteritis. J Med Virol 2:89-96.

105. Bernstein DI, Atmar RL, Lyon GM, Treanor JJ, Chen WH, Jiang X, Vinjé J, Gregoricus N, Frenck RW, Jr, Moe CL, Al-Ibrahim MS, Barrett J, Ferreira J, Estes MK, Graham DY, Goodwin R, Borkowski A, Clemens R, Mendelman PM. 2015. Norovirus vaccine against experimental human GII.4 virus illness: a challenge study in healthy adults. J Infect Dis 211:870-878.
106. Debbink K, Lindesmith LC, Baric RS. 2014. The state of norovirus vaccines. Clin Infect Dis 58:1746-1752.

107. Treanor JJ, Atmar RL, Frey SE, Gormley R, Chen WH, Ferreira J, Goodwin R, Borkowski A, Clemens R, Mendelman PM. 2014. A novel intramuscular bivalent norovirus virus-like particle vaccine candidate: reactogenicity, safety, and immunogenicity in a phase 1 trial in healthy adults. J Infect Dis 210:1763-1771.

108. Podewils LJ, Zanardi Blevins L, Hagenbuch M, Itani D, Burns A, Otto C, Blanton L, Adams S, Monroe SS, Beach MJ, Widdowson M. 2007. Outbreak of norovirus illness associated with a swimming pool. Epidemiol Infect 135:827-833.

109. Widdowson MA, Cramer EH, Hadley L, Bresee JS, Beard RS, Bulens SN, Charles M, Chege W, Isakbaeva E, Wright JG, Mintz E, Forney D, Massey J, Glass RI, Monroe SS. 2004. Outbreaks of acute gastroenteritis on cruise ships and on land: identification of a predominant circulating strain of norovirus: United States, 2002. J Infect Dis 190: 27-36.

110. White PA. 2014. Evolution of norovirus. Clin Microbiol Infect 20:741-745.

111. Xerry J, Gallimore CI, Iturriza-Gómara M, Allen DJ, Gray JJ. 2008. Transmission events within outbreaks of gastroenteritis determined through analysis of nucleotide sequences of the P2 domain of genogroup II noroviruses. J Clin Microbiol 46:947-953.

112. Bitler EJ, Matthews JE, Dickey BW, Eisenberg JN, Leon JS. 2013. Norovirus outbreaks: a systematic review of commonly implicated transmission routes and vehicles. Epidemiol Infect 141:1563-1571.

113. Glass R, Umesh D, Parashar U, Estes M. 2009. Norovirus gastroenteritis. N Engl J Med 361:1776-1785.

114. Kotwal G, Cannon JL. 2014. Environmental persistence and transfer of enteric viruses. Curr Opin Virol 4:37-43.

115. Widdowson MA, Sulka A, Bulens SN, Beard RS, Chaves SS, Hammond R, Salehi ED, Swanson E, Totaro J, Woron R, Mead PS, Bresee JS, Monroe SS, Glass RI. 2005. Norovirus and foodborne disease, United States, 1991-2000. Emerg Infect Dis 11:95-102.

116. Kukkula M, Maunula L, Silvennoinen E, von Bonsdorff CH. 1999. Outbreak of viral gastroenteritis due to drinking water contaminated by Norwalk-like viruses. J Infect Dis 180:1771-1776.

117. Doyle MP, Erickson MC. 2008. Summer meeting 2007-the problems with fresh produce: an overview. J Appl Microbiol 105:317330.

118. Maunula L, Miettinen IT, von Bonsdorff CH. 2005. Norovirus outbreaks from drinking water. Emerg Infect Dis 11:1716-1721.

119. Matthews JE, Dickey BW, Miller RD, Felzer JR, Dawson BP, Lee AS, Rocks JJ, Kiel J, Montes JS, Moe CL, Eisenberg JN, Leon JS. 2012. The epidemiology of published norovirus outbreaks: a review of risk factors associated with attack rate and genogroup. Epidemiol Infect 140:11611172 .

120. Riera-Montes M, Brus Sjölander K, Allestam G, Hallin E, Hedlund KO, Löfdahl M. 2011. Waterborne norovirus outbreak in a municipal drinking-water supply in Sweden. Epidemiol Infect 139:1928-1935.

121. Berg DE, Kohn MA, Farley TA, McFarland LM. 2000. Multi-state outbreaks of acute gastroenteritis traced to fecal-contaminated oysters harvested in Louisiana. J Infect Dis 181:S381-S386.

122. EFSA Panel on Biological Hazards (BIOHAZ). 2012. Norovirus (NoV) in oysters: methods, limits and control options. EFSA J 10:25002539.

123. Le Guyader FS, Krol J, Ambert-Balay K, Ruvoen-Clouet N, Desaubliaux B, Parnaudeau S, Le Saux JC, Ponge A, Pothier P, Atmar RL, Le Pendu J. 2010. Comprehensive analysis of a norovirus-associated gastroenteritis outbreak, from the environment to the consumer. J Clin Microbiol 48:915-920.

124. Lees D. 2000. Viruses and bivalve shellfish. Int J Food Microbiol 59:81-116. 
125. Lopman BA, Reacher MH, Van Duijnhoven Y, Hanon FX, Brown D, Koopmans M. 2003. Viral gastroenteritis outbreaks in Europe, 19952000. Emerg Infect Dis 9:90-96.

126. Thebault A, Teunis PF, Le Pendu J, Le Guyader FS, Denis JB. 2013. Infectivity of GI and GII noroviruses established from oyster related outbreaks. Epidemics 5:98-110.

127. Fitzgerald TL, Merritt TD, Zammit A, McLeod C, Landinez LM, White PA, Munnoch SA, Durrheim DN. 2014. An outbreak of norovirus genogroup II associated with New South Wales oysters. Commun Dis Intell Q Rep 38:E9-E15.

128. Huppatz C, Munnoch SA, Worgan T, Merritt TD, Dalton C, Kelly PM, Durrheim DN. 2008. A norovirus outbreak associated with consumption of NSW oysters: implications for quality assurance systems. Commun Dis Intell Q Rep 32:88-91.

129. Bernard H, Faber, M, Wilking H, Haller S, Höhle M, Schielke A, Ducomble T, Siffczyk C, Merbecks SS, Fricke G, Hamouda O, Stark K, Werber D. 2014. Large multistate outbreak of norovirus gastroenteritis associated with frozen strawberries, Germany, 2012. Euro Surveill 19:20719. https://www.eurosurveillance.org/content/10.2807/1560-7917 .ES2014.19.8.20719.

130. Ethelberg S, Lisby M, Bottiger B, Schultz AC, Villif A, Jensen T, Olsen KE, Scheutz F, Kjelso C, Muller L. 2010. Outbreaks of gastroenteritis linked to lettuce, Denmark, January 2010. Euro Surveill 15:19484. https://www.eurosurveillance.org/content/10.2807/ese.15.06.19484-en.

131. Hennechart-Collette C, Martin-Latil S, Guillier L, Perelle S. 2015. Determination of which virus to use as a process control when testing for the presence of hepatitis A virus and norovirus in food and water. Int J Food Microbiol 202:57-65.

132. Mathijs E, Stals A, Baert L, Botteldoorn N, Denayer S, Mauroy A, Scipioni A, Daube G, Dierick K, Herman L, Van Coillie E, Uyttendaele M, Thiry E. 2012. A review of known and hypothetical transmission routes for noroviruses. Food Environ Virol 4:131-152.

133. Rodríguez-Lázaro D, Cook N, Ruggeri FM, Sellwood J, Nasser A, Nascimento MS, D’Agostino M, Santos R, Saiz JC, Rzeżutka A, Bosch A, Gironés R, Carducci A, Muscillo M, Kovač K, Diez-Valcarce M, Vantarakis A, von Bonsdorff $\mathrm{CH}$, de Roda Husman AM, Hernández M, van der Poel WH. 2012. Virus hazards from food, water and other contaminated environments. FEMS Microbiol Rev 36:786-814.

134. Robilotti E, Deresinski S, Pinsky BA. 2015. Norovirus. Clin Microbiol Rev 28:134-164.

135. La Rosa G, Fontana S, Di Grazia A, Iaconelli M, Pourshaban M, Muscillo M. 2007. Molecular identification and genetic analysis of norovirus genogroups I and II in water environments: comparative analysis of different reverse transcription-PCR assays. Appl Environ Microbiol 73:4152-4161.

136. van den Berg H, Lodder W, van der Poel W, Vennema H, de Roda Husman AM. 2005. Genetic diversity of noroviruses in raw and treated sewage water. Res Microbiol 156:532-540.

137. Bae J, Schwab KJ. 2008. Evaluation of murine norovirus, feline calicivirus, poliovirus, and MS2 as surrogates for human norovirus in a model of viral persistence in surface water and groundwater. Appl Environ Microbiol 74:477-484.

138. Ngazoa ES, Fliss I, Jean J. 2008. Quantitative study of persistence of human norovirus genome in water using TaqMan real-time RT-PCR. J Appl Microbiol 104:707-715.

139. Seitz SR, Leon JS, Schwab KJ, Lyon GM, Dowd M, McDaniels M, Abdulhafid G, Fernandez ML, Lindesmith LC, Baric RS, Moe CL. 2011. Norovirus infectivity in humans and persistence in water. Appl Environ Microbiol 77:6884-6888.

140. Hörman A, Rimhanen-Finne R, Maunula L, von Bonsdorff $\mathrm{CH}$, Torvela N, Heikinheimo A, Hänninen ML. 2004. Campylobacter spp., Giardia spp., Cryptosporidium spp., noroviruses, and indicator organisms in surface water in southwestern Finland, 2000-2001. Appl Environ Microbiol 70:87-95.
141. Lee SG, Jheong WH, Suh CI, Kim SH, Lee JB, Jeong YS, Ko G, Jang KL, Lee GC, Paik SY. 2011. Nationwide groundwater surveillance of noroviruses in South Korea, 2008. Appl Environ Microbiol 77:14661474.

142. Charles KJ, Shore J, Sellwood J, Laverick M, Hart A, Pedley S. 2009. Assessment of the stability of human viruses and coliphage in groundwater by PCR and infectivity methods. J Appl Microbiol 106:1827-1837.

143. Dienus O, Sokolova E, Nyström F, Matussek A, Löfgren S, Blom L, Pettersson TJ, Lindgren PE. 2016. Norovirus dynamics in wastewater discharges and in the recipient drinking water source: long-term monitoring and hydrodynamic modeling. Environ Sci Technol 50:10851-10858.

144. Pusch D, Oh DY, Wolf S, Dumke R, Schröter-Bobsin U, Höhne M, Röske I, Schreier E. 2005. Detection of enteric viruses and bacterial indicators in German environmental waters. Arch Virol 150:929-947.

145. Westrell T, Teunis P, van den Berg H, Lodder W, Ketelaars H, Stenström TA, de Roda Husman AM. 2006. Short- and long-term variations of norovirus concentrations in the Meuse river during a 2-year study period. Water Res 40:2613-2620.

146. Pérez-Sautu U, Sano D, Guix S, Kasimir G, Pintó RM, Bosch A. 2012. Human norovirus occurrence and diversity in the Llobregat River catchment, Spain. Environ Microbiol 14:494-502.

147. Mounts AW, Ando T, Koopmans M, Bresee JS, Noel J, Glass RI. 2000. Cold weather seasonality of gastroenteritis associated with Norwalk-like viruses. J Infect Dis 181:S284-S287.

148. Atmar RL, Opekun AR, Gilger MA, Estes MK, Crawford SE, Neill FH, Graham DY. 2008. Norwalk virus shedding after experimental human infection. Emerg Infect Dis 14:1553-1557.

149. Chan M, Sung J, Lam R. Chan P, Lee N, Lai R, Leung WK. 2006. Fecal viral load and norovirus-associated gastroenteritis. Emerg Infec Dis 12:1278-1280.

150. Flannery J, Keaveney S, Rajko-Nenow P, O’Flaherty V, Doré W. 2012. Concentration of norovirus during wastewater treatment and its impact on oyster contamination. Appl Environ Microbiol 78:3400-3406. 151. Ciocca M. 2000. Clinical course and consequences of hepatitis A infection. Vaccine 18:71-74

152. Bosan A, Qureshi H, Bile KM, Ahmad I, Hafiz R. 2010. A review of hepatitis viral infections in Pakistan. J Pak Med Assoc 60:1045-1058.

153. Shuval H. 2003. Estimating the global burden of thalassogenic diseases: human infectious diseases caused by wastewater pollution of the marine environment. J Water Health 1:53-64.

154. Koff RS. 1998. Hepatitis A. Lancet 351:1643-1649.

155. Franco E, Meleleo C, Serino L, Sorbara D, Zaratti L. 2012. Hepatitis A: epidemiology and prevention in developing countries. World J Hepatol 4:68-73.

156. European Centre for Disease Prevention and Control. 26 June 2017. https://www.ecdc.europa.eu/en/hepatitis-A/facts. Accessed 10 June 2019.

157. CDC. 2020. Widespread person-to-person outbreaks of hepatitis A across the United States. https://www.cdc.gov/hepatitis/outbreaks/2017 March-HepatitisA.htm. Accessed 10 June 2019.

158. Savage RD, Rosella LC, Brown KA, Khan K, Crowcroft NS. 2016. Underreporting of hepatitis A in non-endemic countries: a systematic review and meta-analysis. BMC Infect Dis 16:1-12.

159. Pond K. 2005. Water Recreation and Disease-Plausibility of Associated Infections: Acute Effects, Sequelae and Mortality. World Health Organization, Geneva, Switzerland.

160. Yezli S, Otter JA. 2011. Minimum infective dose of the major human respiratory and enteric viruses transmitted through food and the environment. Food Environ Virol 3:1-30.

161. Jacobsen K. 2009. The Global Prevalence of Hepatitis A Virus Infection and Susceptibility: a Systematic Review. World Health Organization, Geneva, Switzerland.

162. Yong HT, Son R. 2009. Hepatitis A virus: a general overview. Int Food Res J 467:455-467. 
163. Gupta E, Ballani N. 2014. State of the globe: hepatitis a virus-return of a water devil. J Global Infect Dis 6:57-58.

164. Osuolale O, Okoh A. 2015. Incidence of human adenoviruses and hepatitis A virus in the final effluent of selected wastewater treatment plants in Eastern Cape Province, South Africa. Virol J 12:98.

165. Jacobsen KH, Wiersma ST. 2010. Hepatitis A virus seroprevalence by age and world region, 1990 and 2005. Vaccine 28:6653-6657.

166. Yeh HY, Hwang YC, Yates MV, Mulchandani A, Chen W. 2008. Detection of hepatitis A virus by using a combined cell culture-molecular beacon assay. Appl Environ Microbiol 74:2239-2243.

167. Polo D, Varela MF, Romalde JL. 2015. Detection and quantification of hepatitis A virus and norovirus in Spanish authorized shellfish harvesting areas. Int J Food Microbiol 193:43-50.

168. Aggarwal R. 2011. Hepatitis E: historical, contemporary and future perspectives. J Gastroenterol Hepatol 26:72-82.

169. Tam AW, Smith MM, Guerra ME, Huang CC, Bradley DW, Fry KE, Reyes GR. 1991. Hepatitis E virus (HEV): molecular cloning and sequencing of the full-length viral genome. Virology 185:120-131.

170. Hakim MS, Wang W, Bramer WM, Geng J, Huang F, de Man RA, Peppelenbosch MP, Pan Q. 2017. The global burden of hepatitis E outbreaks: a systematic review. Liver Int 37:19-31.

171. Rein DB, Stevens GA, Theaker J, Wittenborn JS, Wiersma ST. 2012. The global burden of hepatitis E virus genotypes 1 and 2 in 2005. Hepatology 55:988-997.

172. Goel A, Aggarwal R. 2016. Advances in hepatitis E. II. Epidemiology, clinical manifestations, treatment and prevention. Expert Rev Gastroenterol Hepatol 10:1065-1074.

173. Kumar S, Subhadra S, Singh B, Panda BK. 2013. Hepatitis E virus: the current scenario. Int J Infect Dis 17:228-233.

174. Lapiński TW, Jaroszewicz J. 2016. Hepatitis E virus infection: a new threat for Europe. Przeglad Epidemiol 70:11-14.

175. Song YJ, Park WJ, Park BJ, Lee JB, Park SY, Song CS, Lee NH, Seo KH, Kang YS, Choi IS. 2014. Hepatitis E virus infections in humans and animals. Clin Exp Vaccine Res 3:29-36.

176. Fierro NA, Realpe M, Meraz-Medina T, Roman S, Panduro A. 2016. Hepatitis E virus: an ancient hidden enemy in Latin America. World J Gastroenterol 22:2271-2283.

177. Park W, Park B, Ahn H, Lee J, Park S, Song C, Lee S, Yoo H, Choi I. 2016. Hepatitis E virus as an emerging zoonotic pathogen. J Vet Sci 17:1-11.

178. Doceul V, Bagdassarian E, Demange A, Pavio N. 2016. Zoonotic hepatitis $\mathrm{E}$ virus: classification, animal reservoirs and transmission routes. Viruses 8:1-25.

179. Dalton HR, Seghatchian J. 2016. Hepatitis E virus: emerging from the shadows in developed countries. Transf Apher Sci 55:271-274.

180. Dalton HR, Bendall R, Ijaz S, Banks M. 2008. Hepatitis E: an emerging infection in developed countries. Lancet Infect Dis 8:698-709.

181. Ferreira CM, Santos JA, Lourenço T, Benoliel C, Matos R, Martins HC. 2013. Diagnóstico da infeção por vírus da hepatite E no INSA 20002012. Bol Epidemiol Observações 10:27-28.

182. Meng XJ. 2010. Hepatitis E virus: animal reservoirs and zoonotic risk. Vet Microbiol 140:256-265.

183. Ruggeri FM, Di Bartolo I, Ponterio E, Angeloni G, Trevisani M, Ostanello F. 2013. Zoonotic transmission of hepatitis $\mathrm{E}$ virus in industrialized countries. New Microbiol 36:331-344.

184. Dalton H, Izopet J. 2018. Transmission and epidemiology of hepatitis E virus genotype 3 and 4 infections. Cold Spring Harb Perspect Med 8:a032144.

185. EFSA. 2017. Hepatitis E: raw pork is main cause of infection in EU. https://www.efsa.europa.eu/en/press/news/170711. Accessed 10 June 2019.

186. Cashdollar JL, Brinkman NE, Griffin SM, Mcminn BR, Rhodes ER, Varughese EA, Grimm AC, Parshionikar SU, Wymer L, Shay Fout G.
2012. Development and evaluation of EPA method 1615 for detection of enterovirus and norovirus in water. Appl Environ Microbiol 79:215-223. 187. Griffin DW, Donaldson KA, Paul JH, Rose JB. 2003. Pathogenic human viruses in coastal waters. Clin Microbiol Rev 16:129-143.

188. Ettayebi K, Crawford SE, Murakami K, Broughman JR, Karandikar U, Tenge VR, Neill FH, Blutt SE, Zeng XL, Qu L, Kou B, Opekun AR, Burrin D, Graham DY, Ramani S, Atmar RL, Estes MK. 2016. Replication of human noroviruses in stem cell-derived human enteroids. Science 353:1387-1393.

189. Iaconelli M, Purpari G, Libera S, Petricca S, Guercio A, Ciccaglione AR, Bruni R, Taffon S, Equestre M, Fratini M, Muscillo M, La Rosa G. 2015. Hepatitis A and E viruses in wastewaters, in river waters, and in bivalve molluscs in Italy. Food Environ Virol 7:316-324.

190. Montazeri N, Goettert D, Achberger EC, Johnson CN, Prinyawiwatkul W, Janes ME. 2015. Pathogenic enteric viruses and microbial indicators during secondary treatment of municipal wastewater. Appl Environ Microbiol 81:6436-6445.

191. Leifels M, Hamza IA, Krieger M, Wilhelm M, Mackowiak M, Jurzik L. 2016. From lab to lake: evaluation of current molecular methods for the detection of infectious enteric viruses in complex water matrices in an urban area. PLoS One 11:1-16.

192. Hamza IA, Jurzik L, Uberla K, Wilhelm M. 2011. Evaluation of pepper mild mottle virus, human picobirnavirus and torque teno virus as indicators of fecal contamination in river water. Water Res 45:1358-68.

193. Rodríguez RA, Pepper IL, Gerba CP. 2009. Application of PCRbased methods to assess the infectivity of enteric viruses in environmental samples. Appl Environ Microbiol 75:297-307.

194. Donia D, Bonanni E, Diaco L, Divizia M. 2010. Statistical correlation between enterovirus genome copy numbers and infectious viral particles in wastewater samples. Lett Appl Microbiol 50:237-240.

195. Hamza IA, Bibby K. 2019. Critical issues in application of molecular methods to environmental virology. J Virol Methods 266:11-24.

196. Harrison CG, Williams PR. 2016. A systems approach to natural disaster resilience. Simul Model Pract Theory 65:11-31.

197. U.S. Environmental Protection Agency. 2016. Climate Change Indicators: Sea Level. https://www.epa.gov/climate-indicators/climate -change-indicators-sea-level.

198. EPA. 2012. Guidelines for Water Reuse. https://www3.epa.gov /region1/npdes/merrimackstation/pdfs/ar/AR-1530.pdf.

199. Gall AM, Mariñas BJ, Lu Y, Shisler JL. 2015. Waterborne viruses: a barrier to safe drinking water. PLoS Pathog 11:1-7.

200. Voulvoulis N. 2018. Water reuse from a circular economy perspective and potential risks from an unregulated approach. Curr Opin Environ Sci Health 2:32-45.

201. Lodder WJ, de Roda Husman AM. 2005. Presence of noroviruses and other enteric viruses in sewage and surface waters in The Netherlands. Appl Environ Microbiol 71:1453-1461.

202. Amenu D. 2014. Wastewater treatment plants as a source of microbial pathogens in receiving watersheds. Res J Chem Environ Sci 2:11-19.

203. Ahmad T, Arshad N, Adnan F, Sadaf Zaidi NU, Shahid MT, Zahoor U, Afzal MS, Anjum S. 2016. Prevalence of rotavirus, adenovirus, hepatitis A virus and enterovirus in water samples collected from different region of Peshawar, Pakistan. Ann Agric Environ Med 23:576-580.

204. Bergamaschi B, Rodrigues MT, Silva JV, Kluge M, Luz RB, Fleck JD, Bianchi E, Silva LB, Spilki FR. 2015. Moving beyond classical markers of water quality: detection of enteric viruses and genotoxicity in water of the Sinos River. Braz J Biol 75:63-67.

205. Sauerbrei A, Wutzler P. 2009. Testing thermal resistance of viruses. Arch Virol 154:115-119.

206. Connell C, Tong HI, Wang Z, Allmann E, Lu Y. 2012. New approaches for enhanced detection of enteroviruses from Hawaiian environmental waters. PLOS ONE 7:1-9. 
207. Fuhrman JA, Liang X, Noble RT. 2005. Rapid detection of enteroviruses in small volumes of natural waters by real-time quantitative reverse transcriptase PCR. Appl Environ Microbiol 71:4523-4530.

208. Jiang SC, Chu W. 2004. PCR detection of pathogenic viruses in southern California urban rivers. J Appl Microbiol 97:17-28.

209. O’Brien E, Nakyazze J, Wu H, Kiwanuka N, Cunningham W, Kaneene JB, Xagoraraki I. 2017. Viral diversity and abundance in polluted waters in Kampala, Uganda. Water Res 127:41-49.

210. Pennino F, Nardone A, Montuori P, Aurino S, Torre I, Battistone A, Delogu R, Buttinelli G, Fiore S, Amato C, Triassi M. 2018. Large-scale survey of human enteroviruses in wastewater treatment plants of a metropolitan area of southern Italy. Food Environ Virol 10:187-192.

211. Prevost B, Lucas FS, Gonçalves A, Richard F, Moulin L, Wurtzer S. 2015. Large scale survey of enteric viruses in river and wastewater underlines the health status of the local population. Environ Int 79:42-50. 212. Updyke EA, Wang Z, Sun S, Connell C, Kirs M, Wong M, Lu Y. 2015. Human enteric viruses: potential indicators for enhanced monitoring of recreational water quality. Virol Sin 30:344-353.

213. Blanco A, Guix S, Fuster N, Fuentes C, Bartolomé R, Cornejo T, Pintó R, Bosch A. 2017. Norovirus in bottled water associated with outbreak, Spain, 2016. Emerg Infect Dis 23:1531-1534.

214. Grøndahl-Rosado RC, Yarovitsyna E, Trettenes E, Myrmel M, Robertson LJ. 2014. A one year study on the concentrations of norovirus and enteric adenoviruses in wastewater and a surface drinking water source in Norway. Food Environ Virol 6:232-245.

215. Hall AJ. 2012. Noroviruses: the perfect human pathogens? J Infect Dis 205:1622-1624.

216. Lee BR, Lee SG, Park JH, Kim KY, Ryu SR, Rhee OJ, Park JW, Lee JS, Paik SY. 2013. Norovirus contamination levels in ground water treatment systems used for food-catering facilities in South Korea. Viruses $5: 1646-1654$.

217. Ahmad T, Anjum S, Zaidi N, Ali A, Waqas M, Afzal MS, Arshad N. 2015. Frequency of hepatitis E and hepatitis A virus in water sample collected from Faisalabad, Pakistan. Ann Agric Environ Med 22:661-664.

218. Béji-Hamza A, Khélifi-Gharbi H, Hassine-Zaafrane M, Della Libera S, Iaconelli M, Muscillo M, Petricca S, Ciccaglione AR, Bruni R, Taffon S, La Rosa G. 2014. Qualitative and quantitative assessment of hepatitis A virus in wastewaters in Tunisia. Food Environ Virol 6:246-252.

219. Dias J, Pinto R, Vieira C, Abreu Corrêa A. 2018. Detection and quantification of human adenovirus (HAdV), JC polyomavirus (JCPyV) and hepatitis A virus (HAV) in recreational waters of Niterói, Rio de Janeiro, Brazil. Mar Pollut Bull 133:240-245.

220. Elmahdy MEI, Fongaro G, Magri ME, Petruccio MM, Barardi CRM. 2016. Spatial distribution of enteric viruses and somatic coliphages in a lagoon used as drinking water source and recreation in Southern Brazil. Int J Hyg Environ Health 219:617-625.

221. Hamza H, Abd-Elshafy DN, Fayed SA, Bahgat MM, El-Esnawy NA, Abdel-Mobdy E. 2017. Detection and characterization of hepatitis A virus circulating in Egypt. Arch Virol 162:1921-1931.

222. Peláez-Carvajal D, Guzmán BL, Rodríguez J, Acero F, Nava G. 2016. Presence of enteric viruses in water samples for consumption in Colombia: challenges for supply systems. Biomedica 36:169-172.

223. Shin E, Kim JS, Oh KH, Oh SS, Kwon MJ, Kim S, Parka J, Kwaka H, Chunga G, Kimc C, Kim J. 2017. A waterborne outbreak involving hepatitis A virus genotype IA at a residential facility in the Republic of Korea in 2015. J Clin Virol 94:63-66.

224. Silva AM, Vieira H, Martins N, Granja ATS, Vale MJ, Vale FF. 2009. Viral and bacterial contamination in recreational waters: a case study in the Lisbon bay area. J Appl Microbiol 108:1023-1031.

225. Baez PA, Lopez MC, Duque-Jaramillo A, Pelaez D, Molina F, Navas MC. 2017. First evidence of the hepatitis $E$ virus in environmental waters in Colombia. PLoS One 12:e0177525.
226. Hellmér M, Paxéus N, Magnius L, Enache L, Arnholm B, Johansson A, Bergström T, Norder H. 2014. Detection of pathogenic viruses in sewage provided early warnings of hepatitis A virus and norovirus outbreaks. Appl Environ Microbiol 80:6771-6781.

227. La Rosa G, Pourshaban M, Iaconelli M, Vennarucci VS, Muscillo M. 2010. Molecular detection of hepatitis E virus in sewage samples. Appl Environ Microbiol 76:5870-5873.

228. La Rosa G, Proroga Y, De Medici D, Capuano F, Iaconelli M, Della Libera S, Suffredini E. 2018. First detection of hepatitis E virus in shellfish and in seawater from production areas in southern Italy. Food Environ Virol 10:127-131.

229. Dongdem JT, Adjimani J, Armah G. 2010. Detection and characterization of human rotavirus in tap water by multiplex RT-PCR. Int J Med Med Sci 1:223-230.

230. Gratacap-Cavallier B, Genoulaz O, Soule H, Bost M, Gofti L, Zmirou D, Seigneurin JM. 2000. Detection of human and animal rotavirus sequences in drinking water. Appl Environ Microbiol 66:2690-2692.

231. Lodder WJ, Berg HHJL, Rutjes SA, Husman AMDR. 2010. Presence of enteric viruses in source waters for drinking water production in the Netherlands. Appl Environ Microbiol 76:5965-5971.

232. Rutjes SA, Lodder WJ, Leeuwen A, Husman A. 2009. Detection of infectious rotavirus in naturally contaminated source waters for drinking water production. J Appl Microbiol 107:97-105.

233. Haramoto E, Fujino S, Otagari M. 2015. Distinct behaviors of infectious F-specific RNA coliphage genogroups at a wastewater treatment plant. Sci Total Environ 520:32-38.

234. Schmitz BW, Kitajima M, Campillo ME, Gerba CP, Pepper IL. 2016. Virus reduction during advanced Bardenpho and conventional wastewater treatment processes. Environ Sci Technol 50:9524-9532.

235. Lee CS, Lee C, Marion J, Wang Q, Saif L, Lee J. 2014. Occurrence of human enteric viruses at freshwater beaches during swimming season and its link to water inflow. Sci Total Environ 472:757-766.

236. Lin J, Singh A. 2015. Detection of human enteric viruses in Umgeni River, Durban, South Africa. J Water Health 13:1098-1112.

237. Maurer CP, Simonetti AB, Staggemeier R, Rigotto C, Heinzelmann LS, Spilki FR. 2015. Adenovirus, enterovirus and thermotolerant coliforms in recreational waters from Lake Guaíba beaches, Porto Alegre, Brazil. J Water Health 13:1123-1129.

238. Hamza IA, Jurzik L, Stang A, Sure K, Uberla K, Wilhelm M. 2009. Detection of human viruses in rivers of a densly-populated area in Germany using a virus adsorption elution method optimized for PCR analyses. Water Res 43:2657-2668.

239. Borchardt MA, Spencer SK, Kieke BA, Lambertini E, Loge FJ. 2012. Viruses in nondisinfected drinking water from municipal wells and community incidence of acute gastrointestinal illness. Environ Health Perspect 120:1272-1279.

240. El-Senousy W, Abdel-Moneim A, Abdel-Latif M, El-hefnawy M, Khalil G. 2018. Coxsackievirus B4 as a causative agent of diabetes mellitus type 1 : is there a role of inefficiently treated drinking water and sewage in virus spreading? Food Environ Virol 10:89-98.

241. Aslan A, Xagoraraki I, Simmons FJ, Rose JB, Dorevitch S. 2011. Occurrence of adenovirus and other enteric viruses in limited-contact freshwater recreational areas and bathing waters. J Appl Microbiol 1:1250-1261.

242. Rose MA, Dhar AK, Brooks HA, Zecchini F, Gersberg RM. 2006. Quantitation of hepatitis A virus and enterovirus levels in the lagoon canals and Lido beach of Venice, Italy, using real-time RT-PCR. Water Res 40:2387-2396.

243. Staggemeier R, Heck TMS, Demoliner M, Ritzel RGF, Röhnelt NMS, Girardi V, Venker C, Spilki FR. 2017. Enteric viruses and adenovirus diversity in waters from 2016 Olympic venues. Sci Total Environ 586:304-312.

244. Kazama S, Masago Y, Tohma K, Souma N, Imagawa T, Suzuki A, Liu X, Saito M, Oshitani H, Omura T. 2016. Temporal dynamics of 


\section{Teixeira et al.}

norovirus determined through monitoring of municipal wastewater by pyrosequencing and virological surveillance of gastroenteritis cases. Water Res 92:244-253.

245. Pouillot R, Van Doren JM, Woods J, Plante D, Smith M, Goblick G, Roberts C, Locas A, Hajen W, Stobo J, White J, Holtzman J, Buenaventura E, Burkhardt W III, Catford A, Edwards R, DePaola A, Calci KR. 2015. Meta-analysis of the reduction of norovirus and malespecific coliphage concentrations in wastewater treatment plants. Appl Environ Microbiol 81:4669-4681.

246. Iwai M, Hasegawa S, Obara M, Nakamura K, Horimoto E, Takizawa T, Kurata T, Sogen S, Shiraki K. 2009. Continuous presence of noroviruses and sapoviruses in raw sewage reflects infections among inhabitants of Toyama, Japan (2006 to 2008). Appl Environ Microbiol 75:1264-1270.

247. Eftim SE, Hong T, Soller J, Boehm A, Warren I, Ichida A, Nappier SP. 2017. Occurrence of norovirus in raw sewage: a systematic literature review and meta-analysis. Water Res 111:366-374.

248. Nordgren J, Matussek A, Mattsson A, Svensson L, Lindgren PE. 2009. Prevalence of norovirus and factors influencing virus concentrations during one year in a full-scale wastewater treatment plant. Water Res 43:1117-25.

249. da Silva AK, Le Saux JC, Parnaudeau S, Pommepuy M, Elimelech M, Le Guyader FS. 2007. Evaluation of removal of noroviruses during wastewater treatment, using real-time reverse transcription-PCR: different behaviors of genogroups I and II. Appl Environ Microbiol 73: 7891-7897.
250. López-Gálvez F, Truchado P, Sánchez G, Aznar R, Gil MI, Allende A. 2016. Occurrence of enteric viruses in reclaimed and surface irrigation water: relationship with microbiological and physicochemical indicators. J Appl Microbiol 121:1180-1188.

251. Haramoto E, Katayama H, Oguma K, Ohgaki S. 2005. Application of cation-coated filter method to detection of noroviruses, enteroviruses, adenoviruses, and torque teno viruses in the Tamagawa River in Japan. Appl Environ Microbiol 71:2403-2411.

252. Ouardani I, Manso CF, Aouni M, Romalde JL. 2015. Efficiency of hepatitis A virus removal in six sewage treatment plants from central Tunisia. Appl Microbiol Biotechnol 99:10759-10769.

253. Chigor VN, Sibanda T, Okoh AI. 2014. Assessment of the risks for human health of adenoviruses, hepatitis A virus, rotaviruses and enteroviruses in the Buffalo River and three source water dams in the Eastern Cape. Food Environ Virol 6:87-98.

254. Sibanda T, Okoh AI. 2013. Real-time PCR quantitative assessment of hepatitis A virus, rotaviruses and enteroviruses in the Tyume River located in the Eastern Cape Province, South Africa. Water SA 39:295-304.

255. Wang H, Sikora P, Rutgersson C, Lindh M, Brodin T, Björlenius B, Larsson DGJ, Norder H. 2018. Differential removal of human pathogenic viruses from sewage by conventional and ozone treatments. Int J Hyg Environ Health 221:479-488.

256. Masclaux FG, Hotz P, Friedli D, Savova-Bianchi D, Oppliger A. 2013. High occurrence of hepatitis $E$ virus in samples from wastewater treatment plants in Switzerland and comparison with other enteric viruses. Water Res 47:5101-5109. 